University of San Diego

Digital USD

2014-06-01

\title{
Services for Parentally Placed Catholic School Students under the Individuals with Disabilities Education Improvement Act
}

Julie Cantillon PhD

University of San Diego

Follow this and additional works at: https://digital.sandiego.edu/dissertations

Part of the Leadership Studies Commons

\section{Digital USD Citation}

Cantillon, Julie PhD, "Services for Parentally Placed Catholic School Students under the Individuals with Disabilities Education Improvement Act" (2014). Dissertations. 851.

https://digital.sandiego.edu/dissertations/851

This Dissertation: Open Access is brought to you for free and open access by the Theses and Dissertations at Digital USD. It has been accepted for inclusion in Dissertations by an authorized administrator of Digital USD. For more information, please contact digital@sandiego.edu. 
SERVICES FOR PARENTALLY PLACED CATHOLIC SCHOOL STUDENTS UNDER THE INDIVIDUALS WITH DISABILITIES EDUCATION IMPROVEMENT ACT

by

\author{
Julie Cantillon
}

A dissertation submitted in partial fulfillment

of the requirements for the degree of

Doctor of Philosophy

June 2014

Dissertation Committee

Frank Kemerer, Ph.D.

Margaret Dalton, J.D.

Afsaneh Nahavandi, Ph.D.

University of San Diego 


\begin{abstract}
The Individuals with Disabilities Education Act (IDEA), which Congress enacted in 1975 with subsequent revisions, states that school districts are to provide a free and appropriate public education (FAPE) to all students with disabilities in the least restrictive environment. Public local education agencies (LEAs) including school districts have an obligation to identify, locate, and evaluate private school students suspected of having a disability - the "child find" process. Students enrolled by their parents in private schools are not entitled to a FAPE if they choose for their children to remain in private school after the children have been identified as having a disability and offered services by the LEA. However, a portion of IDEA funding to LEAs provides limited services for identified students with disabilities enrolled in private schools.
\end{abstract}

The purpose of this study was to gain an understanding of the efficacy of the child find process in the Diocese of San Diego for Catholic schools within the boundaries of the San Diego Unified School District (SDUSD). The initial focus was on special education law to describe how it applies in the public and private school context. Thereafter, data are presented based on an electronic survey that was administered to 19 principals of Catholic schools in the spring of 2013 with five follow-up interviews to learn how much understanding Catholic school principals have about both child find and special education services under IDEA, as well as what services are being provided to students with disabilities in their schools.

The study found that most administrators in the Diocese of San Diego within the boundaries of SDUSD have a limited working knowledge of the child find process. The implications of this include an inaccurate reporting to the school district of the number of 
identified students in these schools. The inaccurate reporting adversely affects the amount of IDEA funds reserved for students attending Catholic schools and therefore the level of services that can be offered by the LEA within the private school setting.

Drawing upon these data, the dissertation provides recommendations for improving public special education services for children enrolled in Catholic schools. 
(C) Copyright by Julie Cantillon, 2014 All Rights Reserved 


\section{Dedication}

To Sister Mary Kiely, OSF who led me to begin this journey. 


\section{ACKNOWLEDGMENTS}

Over the past seven years I have received encouragement and support from many individuals. Dr. Frank Kemerer, my dissertation chair, has been an amazing mentor throughout this process. I owe a debt of gratitude to him for spending countless hours communicating with me and providing me with invaluable feedback throughout my writing process. His guidance has made this a thoughtful and rewarding journey. I would also like to thank my dissertation committee members. Margaret A. Dalton J.D. was a tremendous legal resource for the past two years as I moved from ideas to a completed study. Also, my sincerest thanks to Dr. Afsaneh Nahavandi who came to the rescue and served as my third committee member when my deadline loomed.

Additionally, I would like to thank my family and friends who listened and encouraged me throughout the years and gave me words of encouragement when I needed them most. Special thanks to my mother who served as an editor for many research papers I had to submit. Finally, I would like to thank Sister Mary Kiely who inspired me to pursue a doctorate at the University of San Diego. 


\section{TABLE OF CONTENTS}

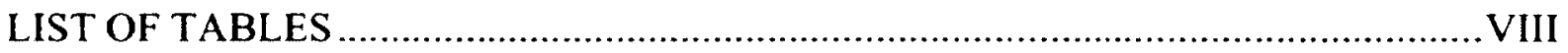

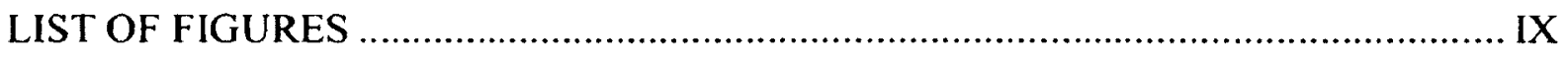

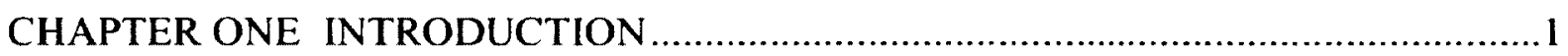

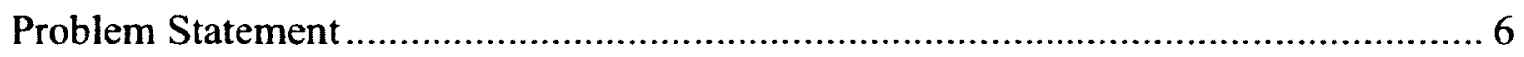

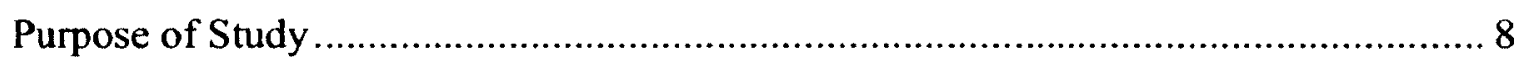

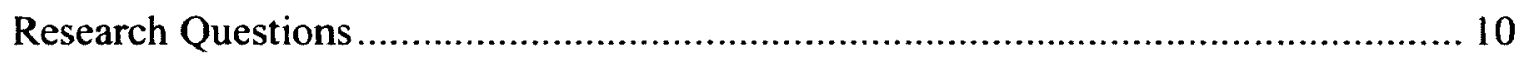

CHAPTER TWO LITERATURE REVIEW ……...............................................

Private School Special Education Law .............................................................. 11

Annual Expenditures for Private School Special Education Students........................ 13

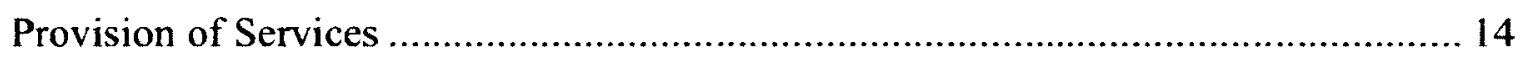

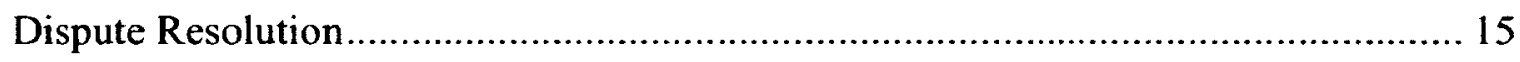

Admissions Policies for Students With Disabilities in Private Schools ..................... 16

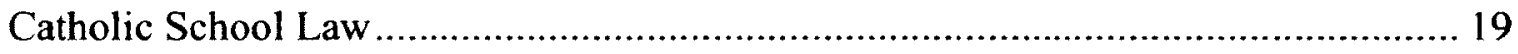

Research on Catholic Schools and Students With Disabilities................................ 22

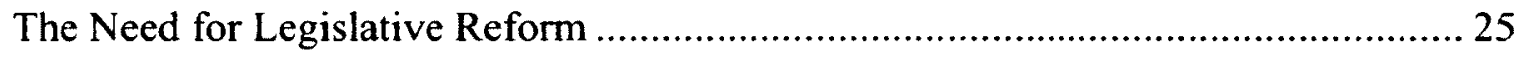

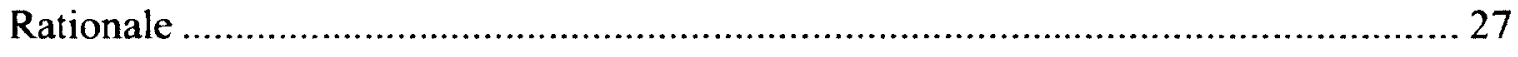

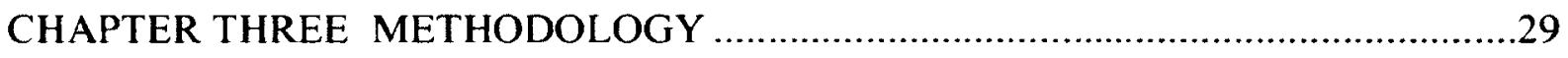

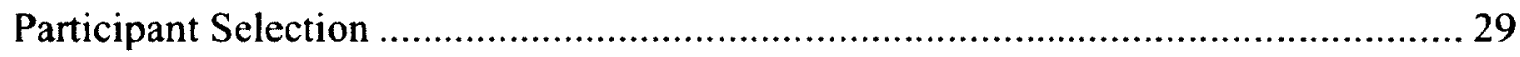

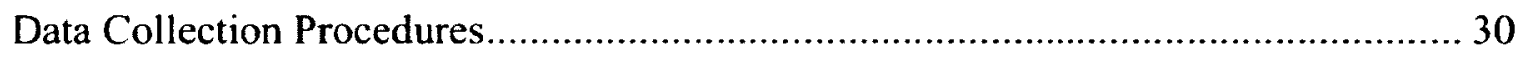

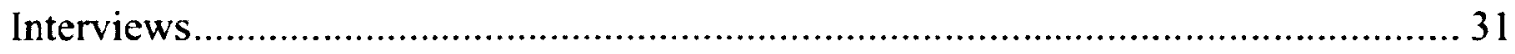

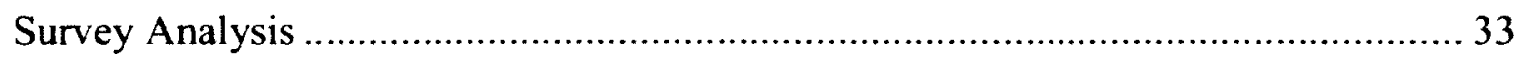

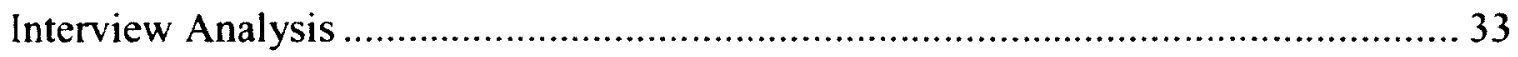


Methodological Limitations of the Study ................................................ 34

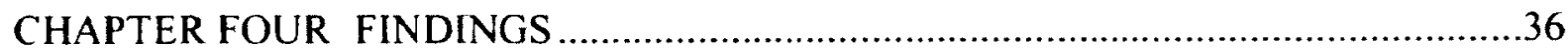

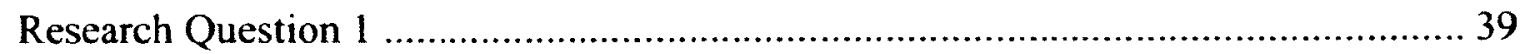

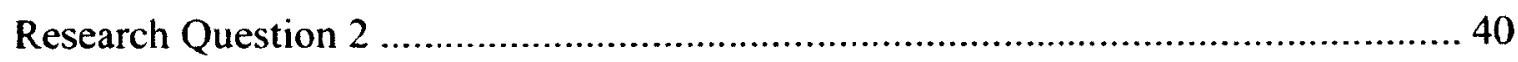

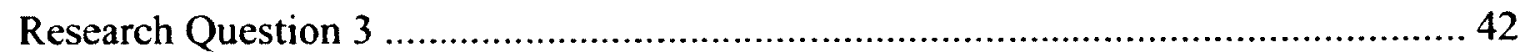

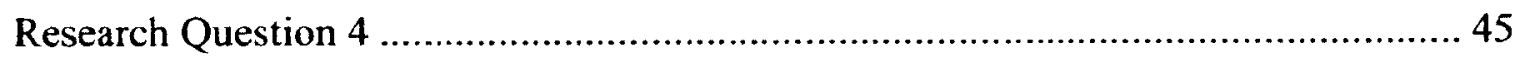

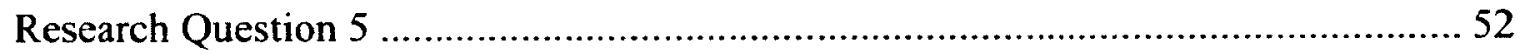

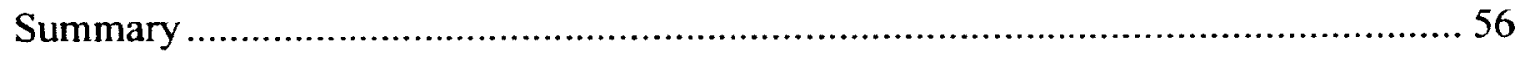

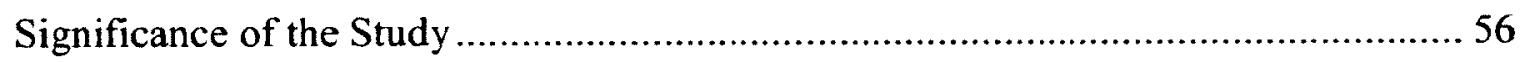

CHAPTER FIVE RESEARCH SUMMARY, IMPLICATIONS, AND

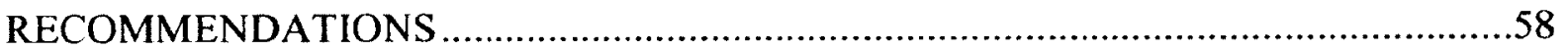

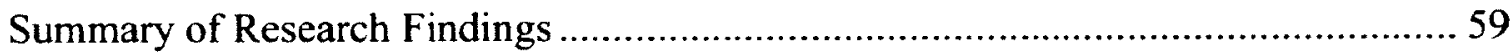

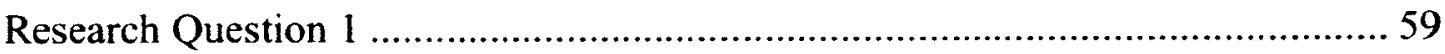

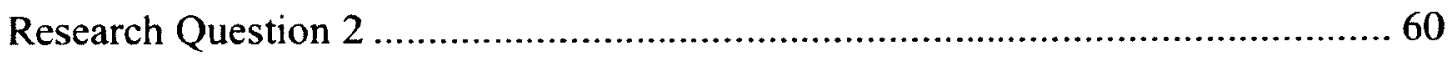

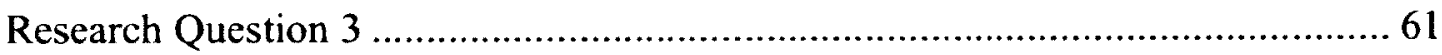

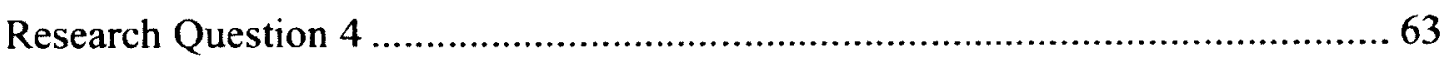

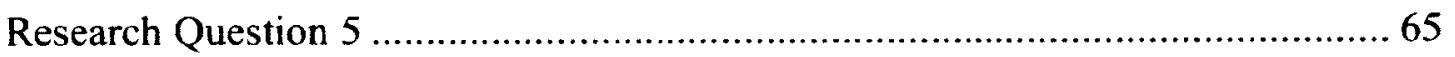

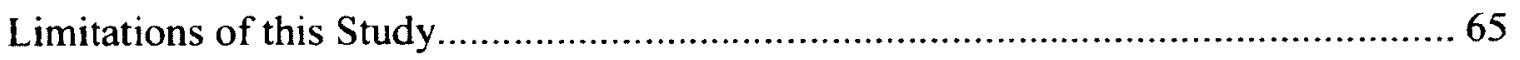

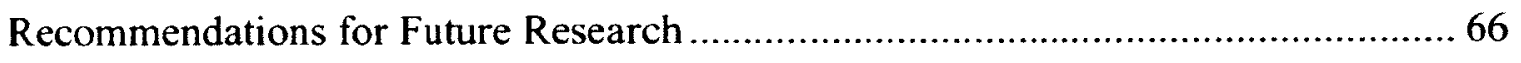

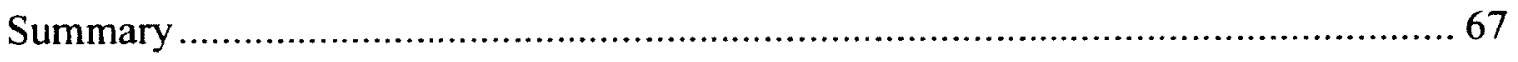

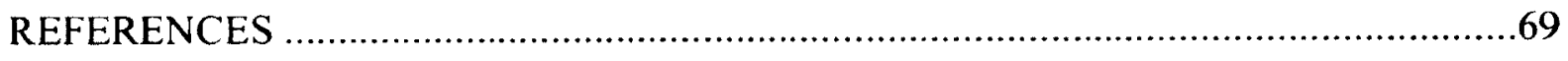




\section{LIST OF TABLES}

Table 1. Students with identified disabilities enrolled in Catholic and public schools .... 23

Table 2. Descriptive statistics for the research questions .................................... 38

Table 3. Administrators reporting one or more students enrolled with learning disabilities 43

Table 4. Number of administrators reporting occurrence of indirect services 52 


\section{LIST OF FIGURES}

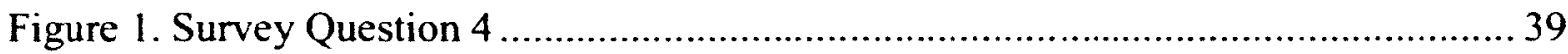

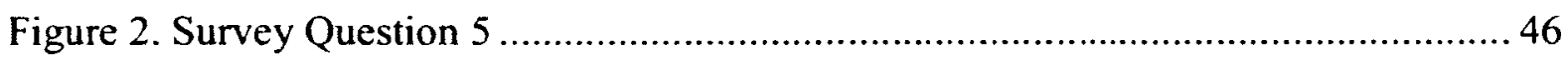

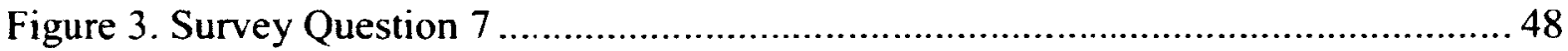

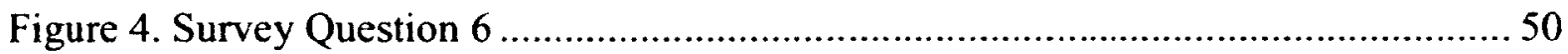

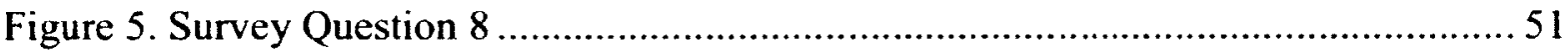

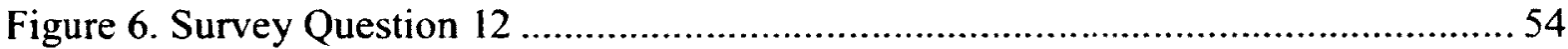

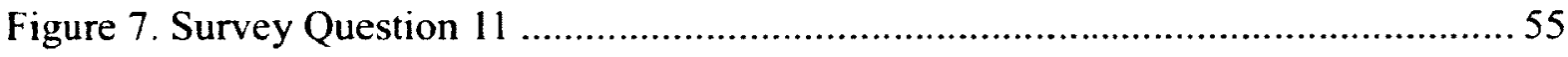




\section{CHAPTER ONE}

\section{INTRODUCTION}

In the United States, the provision of education to students with disabilities is governed by four federal laws: the Individuals With Disabilities Education Improvement Act IDEA (2004), Section 504 of the Rehabilitation Act (1973), the Americans With Disabilities Act of 1990 (ADA), and the No Child Left Behind Act (NCLB, 2002). In addition to the federal laws, each state has its own laws governing special education (Russo, Osborne, Massucci, \& Cattaro, 2009). IDEA has been critical in ensuring the provision of a free and appropriate public education (FAPE) to eligible students who have disabilities (Katsiyannis \& Maag, 2009).

In 1975, Congress passed the Education for All Handicapped Children Act. In 1990, Congress amended this legislation and gave the law its current title, IDEA. IDEA went through further revisions in 1997 and again in 2004. ${ }^{1}$ This act requires states and school districts to provide a FAPE to all students in the least restrictive environment (20 U.S.C.A. $\S 1412(a)(5)(A))$. To receive services, students must be between the ages of 3 and 21 , must have identified disabilities, and special education services must be deemed necessary to receive a FAPE in accordance with the individualized education program (IEP). Students with disabilities may also receive related services, such as transportation and physical therapy as part of their IEPs.

\footnotetext{
'At the time of this study, IDEA is sometimes referred to as "IDEA 2004." When referenced in this dissertation, the acronym "IDEA" encompasses the revisions in 1997 and 2004.
} 
A number of safeguards are in place to protect the rights of students and their parents. As part of IDEA, schools must contact the parents in writing and obtain parental consent before evaluating students, making placements, or changing placements ( 34 C.F.R. $\S 300.300 ; 20$ U.S.C.A. $§ 1414(a)(1)(D)(i))$. Additionally, parents must be given the opportunity to participate in the IEP and placement processes. IEPs must be reviewed annually, at the minimum, and students must be reevaluated at least once every 3 years (20 U.S.C.A. $\$ 1414(a)(2)(B))$. However, if the parents and school agree in writing every 3 years that subsequent evaluations are unnecessary, then they are not required.

Furthermore, there are provisions in IDEA supplemented by the Family Educational Rights and Privacy Act, which protect the confidentiality of all of the students' information in the evaluation and placement processes (20 U.S.C.A. $§ 1232 \mathrm{~g})$. Private schools are not required to implement the mandates of IDEA. Nonetheless, school boards are required to spend a proportionate share of their federal special education dollars on students who attend private schools.

Section 504 of the Rehabilitation Act of 1973 was the first federal civil rights law aimed at protecting the rights of individuals with disabilities. The statute stated,

No otherwise qualified individual with a disability in the United States...shall, solely by reason of her or his disability, be excluded from the participation in, be denied the benefits of, or be subjected to discrimination under any program or activity receiving federal financial assistance. (29 U.S.C.A. $§ 794(a)$ )

All institutions that receive federal financial assistance are subject to the provisions in Section 504. The courts have broadly interpreted this term; therefore, it applies to all public schools and, as noted below, some private schools as well. However, there is an exemption if the basis of exclusion is rooted in religious tenets. Section 504 provides protection to children and all adults who visit or work at the educational institutions 
under the concept of impairment, not disability (34 C.F.R. $\S 104.3(j)(2)(i) ; 42$ U.S.C.A. $\S$ $12102(1))$

Once students are identified as having disabilities under Section 504, they are entitled to an equal opportunity to participate in an education program no matter the nature or severity of their impairments (34 C.F.R. $\S 104.4(b)(2) ; 20$ U.S.C.A. $\S 1706$ ). Section 504's regulations include due process requirements to guarantee that an appropriate education is being provided; however, they are not nearly as extensive as those under IDEA. When making accommodations for students with impairments, schools must provide aid and services comparable to their peers who do not have identified impairments. Programs for students who qualify should not be separate from programs for other students unless segregation is necessary for the educational program to be effective (20 U.S.C.A. $\$ 1412(a)(5)(A)$ ). Schools may offer separate programs for students who have impairments, but students are not required to attend such classes if they could be offered in a more inclusive setting.

Section 504 is based on an institution's receiving any form of federal financial assistance (34 C.F.R. $\S 104.4(a)$ ). However, it may be applicable to private schools even if they do not receive direct funding because "direct funding" can be interpreted generally (Russo et al., 2009). Funding may also be in the form of grants, assistance programs, materials, or school lunch subsidies. Even if a private school only receives funding for one such program, it is considered to be a recipient of federal financial assistance (Cain v. Archdiocese of Kansas, 1981).

Section 504 asserted that schools cannot exclude students on the basis of their impairments if only reasonable adjustments need to be provided to receive an appropriate 
education (34 C.F.R. $§ 104.39(a)$ ). Additionally, a Section 504 regulation stated that private schools "may not charge more for the provision of an appropriate education to handicapped persons than to nonhandicapped persons except to the extent that any additional charge is justified by a substantial increase in cost to the recipient" ( 34 C.F.R. $\S 104.39(\mathrm{~b}))$. A recipient is defined as

any state or its political subdivision, any instrumentality of a state or its political subdivision, any public or private agency, institution, organization, or other entity, or any person to which Federal financial assistance is extended directly or through another recipient, including any successor, assignee, or transferee of a recipient, but excluding the ultimate beneficiary of the assistance (34 C.F.R. $\S 104.3(f)$ ).

Thus, private schools may in fact charge additional fees to families of students with impairments if faced with a potential substantial increase in cost (34 C.F.R. $\S$ 104.39(b)).

The ADA (1990) built on Section 504 by affording persons with disabilities access to most places of business in the country. The ADA also forbid discrimination against persons with disabilities in the public and private sectors. Employers are required to make reasonable accommodations for employees with disabilities so they can carry out their jobs. These accommodations may include the acquisition or modification of devices or the provision of qualified readers or interpreters (42 U.S.C.A. $\$ 12111(9)(B)$ ). In education, some examples of reasonable accommodations, which are also available under Section 504, include written materials in alternative formats, rescheduling classes to more accessible locations, and making testing adjustments (National Association of Independent Schools [NAIS], 2006). This statute does, however, provide an exemption for religious organizations (42 U.S.C.A. $§ 12187$ ). Therefore, religious schools are exempt from ADA. 
NCLB (20 U.S.C.A. $\S 6301$ et seq.), which is an extension of the original Elementary and Secondary Education Act of 1965, does not directly apply to private schools; however, it could potentially affect how special education services are delivered in all educational situations. In many cases, NCLB provides benefits to private schools, including religiously affiliated schools because federal tax dollars are the revenue source (20 U.S.C.A. $§ 6320$ ). The main provisions of the NCLB are aimed at improving the academic achievement of students who come from economically disadvantaged homes; assisting in preparing and recruiting highly qualified teachers providing English language learners with improved language instruction; holding school districts accountable for student achievement, specifically by requiring standards for annual yearly progress; and mandating school districts to utilize research based teaching methods.

There are several entitlement programs within NCLB that could apply to private school eligible students and teachers, and two are described (20 U.S.C.A. $§ 6320)$. Expenditures by a local education agency (LEA) under these two entitlements for private school students must be equal to those of its public school counterparts (34 C.F.R. $\S$ 200.64(a)). The first program is Title I: Improving the Academic Achievement of the Disadvantaged. Under Title I, LEAs are required to provide services for eligible private school students, along with eligible public school students. Specifically, section 1120 of Title I, Part A of the ESEA, requires a participating LEA to provide eligible children attending private elementary and secondary schools, their teachers, and their families with Title I services or other benefits that are equitable to those provided to eligible public school children, their teachers, and their families. For students to be eligible, they must reside in a Title 1 attendance area and be failing or at risk of failing (20 U.S.C.A. $\S$ 
$6301(2))$. The school district provides a list of eligible students to the private schools, and students receive services provided by a district employee or a contractor, such as the private school teacher during nonschool hours. Services may include private tutoring, counseling, or instructional services outside of the classroom (34 C.F.R. $\S 200.45(a)$ ).

Title II, Part A, is the Training and Recruiting High-Quality Teachers and Principals program (20 U.S.C.A. $\S 6319$ ). This program provides teacher and principal trainings for teachers working in private schools. Services can be provided in a number of ways; typically, programs are coordinated using a third-party contractor (34 C.F.R. § 200.64(b)(3)(i)). Programs could include training in the use of data and assessments to improve instruction or working with students who have varying learning styles. Professional development must align to the needs of private school educators.

No funds are distributed directly to the private schools, only materials and services. The services offered are considered assistance to teachers and students, not the private schools themselves (34 C.F.R. $\S 300.144(c)(1))$. The private school administrators are tasked with initiating the process, so it is necessary for them to be aware of the provisions set forth in NCLB as they develop their own standards for a quality education because it lays out the standards for achievement and accountability in public schools (Russo et al., 2009).

\section{Problem Statement}

Many private schools enroll students with identified disabilities; however, there is scarce literature that shows the type of services provided to students in private schools by the LEA (Taylor, 2005). Additionally, the percentage of identified students with disabilities in public schools is almost double (13.3\%) the percentage of students in 
Catholic schools $(6.83 \%$; USCCB, 2002). Unfortunately, the study conducted in 2002 is the latest study of its kind. It is unclear whether the results are due to admissions' policies; a flaw with the child find process of identifying, locating, and evaluating students with suspected disabilities; or other factors.

The implementation of IDEA has failed to assure that services for students in private schools correspond to student needs as explicitly stated in IDEA (Wasserman, 2009). Services are typically "indirect," such as "Make it-Take it" workshops held in SDUSU for private school teachers. This is a biannual event where private school teachers are invited to make instructional materials to use in their classrooms (SDUSU, 2013). According to the flyer, the event is open to any teachers working at schools who have students on special education individualized services plans. The flyer stated that teachers are welcome to "design your own materials or personalize materials including enlargements and laminating."

Funding for IDEA is on a proportionate share basis, which means that the amount available for parentally placed children with disabilities in private schools is a proportion of the total amount made available to the LEA for all students with disabilities in the LEA's jurisdiction (U.S. Department of Education, 2004). In short, fewer students in private schools are identified as having disabilities translates to less funding for special education services for these students.

At a recent special education meeting for private school educators in the SDUSD, data were shared revealing that in the 2011-2012 school year, there were 15,208 special education students enrolled in the public schools in SDUSD. Conversely, there were only 169 students enrolled in private schools who had been determined to be eligible to 
be on the SDUSD special education caseload. Because funding is proportionate, that number translates to private school students only receiving a total of $0.0111 \%$ of the funding allocated for all of the students residing in the SDUSD, according to the Parentally Placed Private School Services division (PPPSS, 2012). There's a need to explore the efficacy of the child find process in educating Catholic school representatives.

\section{Purpose of Study}

The purpose of this study is to gain a deeper understanding of the efficacy of the child find process in educating Catholic school representatives. If administrators are not knowledgeable about the child find process, it is highly unlikely that they could advocate for their students who have suspected disabilities. This study may also help to determine the extent to which students with disabilities are enrolled in Catholic schools within the boundaries of the SDUSD. Finally, this study helps identify the types of services are made available for students who are identified by the LEA or Catholic school as having a disability.

The focus on Catholic schools in the study, and not nonreligious private schools, is intentional. In the field of education, Catholic schools can serve as a strong role model in social justice education. Although the larger field of education as a whole pursues social justice by attempting to ameliorate marginalization in schools, there are several factors that make Catholic schools unique.

Pursuing social justice is at the core of the Catholic identity of Catholic schools. However, Catholic schools have not been historically as successful as public schools in educating students with special needs. This limited success is due to a number of 
reasons, predominantly because of financial limitations (Scanlan, 2009). Policies and practices are enacted that generally reflect Catholic social teaching and the emphasis of human dignity, the common good, and preferential option for the marginalized.

Nevertheless, Scanlan (2009) argued, "Catholic schools cannot claim to be truly Catholic if they do not diligently strive to adhere to the fundamental teachings of the Church, and CST unambiguously compels Catholic institutions to treat those on the margins with dignity" (p. 7). However, Catholic schools, along with other private schools, tend to be more exclusionary than public schools by design (Scanlon, 2009). Families choose to enroll their children in private education and have considerable discretion in the admissions and enrollment process.

Although Catholic schools do employ some of these exclusionary processes common to all private schools, they also have an additional level of complexity. Catholic schools tend to be more heterogeneous than nonreligious private schools. For example, less than half $(49.5 \%)$ of private schools enroll students in poverty; however, $68.9 \%$ of Catholic schools do. Catholic schools are also more racially and ethnically diverse nationally than other private schools (Alt \& Peter, 2002). According to the National Catholic Educational Association website, in the 2012-2013 school year, 19.6\% of students enrolled were racial minorities, $14.3 \%$ were Hispanic/Latino and $6.4 \%$ were reported as unknown in the racial data collection. In the Catholic schools located within the boundaries of SDUSD, approximately $40 \%$ of total Catholic school enrollment are students of color (Diocese of San Diego Office for Schools, 2013). The religious mission of Catholic schools compels them to reach out and be accepting of traditionally marginalized students (Scanlan, 2009). 


\section{Research Questions}

The following questions guided this study:

1. How knowledgeable are Catholic school administrators about the child find process?

2. What strategies does SDUSD use to make Catholic school administrators aware of the process?

3. To what extent are children with disabilities enrolled in Catholic schools in the Diocese of San Diego?

4. Given IDEA 2004 regulations, how does the child find process operate for parentally placed Catholic school children who may have a disability?

5. How and to what extent do Catholic school students with disabilities receive special education and related services through IDEA 2004 ? 


\section{CHAPTER TWO \\ LITERATURE REVIEW \\ Private School Special Education Law}

When IDEA was reauthorized in 1997, it included provisions that spelled out the obligations of public school systems. The 2004 amendments added more clarification as did the Part B regulations in 2006. According to IDEA, students whose parents voluntarily place their children in private schools are eligible for education services, although they do not have individual entitlement to services (20 U.S.C.A. § 1412(a)(3)(A)). IDEA did permit the special education services to take place on site at the private school (20 U.S.C.A. $\S 1412(a)(10)(i)(I I I))$. IDEA defined a private school student as one who is voluntarily enrolled in a private school by his or her parent(s)/guardian(s) (34 CFR § 300.130).

Modifications of IDEA in 2004 required public school officials to identify children with disabilities who are attending private schools in their districts. Public schools need to provide state education agencies with the accurate number of students enrolled in private schools whom they have tested, determined to have disabilities, and served (34 C.F.R. $\S 300.131$ (b)(2)). School board officials are required to use these socalled "child find" activities to identify children in private schools similar to those used to identify students in public schools. The cost of child find activities does not count toward the proportional spending formula explained later.

As part of child find, districts need to begin identifying eligible children at birth. The child find duties are "affirmative," which means that the parent is not required to request an evaluation. The child find process is comprehensive and extends to all 
children with disabilities enrolled in private independent and private religious elementary and secondary schools. The process must ensure equitable participation and an accurate count of parentally placed children in private schools. The child find process is the obligation of the LEA where the private school is located (34 C.F.R. $\S 300.137(c)(1)$ ). This obligation is contrasted with IDEA/97's child find stipulation that the LEA where the child's parents resided was responsible for conducting the process (Wasserman, 2009). According to NCLB (2002), the term local educational agency is defined as a public board of education or other public authority legally constituted within a State for either administrative control or direction of, or to perform a service function for, public elementary schools or secondary schools in a city, county, township, school district, or other political subdivision of a State, or for such a combination of school districts or counties as are recognized in a State as an administrative agency for its public elementary schools or secondary schools (20 U.S.C.A. $\$ 1401(19)(A))$.

The law regarding child find states that all activities must be completed within a similar amount of time as they would for students attending public schools. School districts are required to meet with representatives from private schools to assist in the creation of child find procedures. Again, the cost of child find activities cannot be counted as part of the proportioned spending amount for students with disabilities enrolled in public schools. If the parents of a private school student allege a child find violation has been made, they can use the IDEA due process complaint hearing procedure. Under these conditions, the complainant must show that the school district did not satisfy its obligation to identify, locate, or evaluate the private school student (20 U.S.C.A. $\S$ 1412(a)(10)(A)(ii)).

IDEA requirements incorporate the U.S. Department of Education administrative regulations. These regulations require local school districts to offer students enrolled in private schools the opportunity to participate in federal programs that are equivalent to 
programs provided to students enrolled in public schools. In developing programs, public school officials need to confer with private school personnel to take into account what benefits students in private schools will receive, how they will be received, and how programs will be evaluated (20 U.S.C.A. § 1412(a)(10)(A)(i)(II)).

\section{Annual Expenditures for Private School Special Education Students}

IDEA set a spending cap on the amount of money that public school boards are required to spend when providing special education services to students enrolled in private schools (20 U.S.C.A. $\S 1412(a)(10)(A)(i)(1))$. The amount is calculated on a proportionate share basis--the total number of students in public schools with disabilities residing in the jurisdiction of the LEA who are eligible to receive services as compared with the total number of eligible parentally placed private school students with disabilities in the LEA's jurisdiction (20 U.S.C.A. § 1412(a)(10)(A)(i)(I)). School boards can use state funds to offer more than IDEA requires because the regulations only set forth a minimum amount of money that must be spent on eligible students enrolled in private schools (20 U.S.C.A. §1412(a)(10)(A)(i)(IV)).

Funds from IDEA cannot be used to benefit a private school financially. Public funds cannot finance existing private school educational programs or be used to organize classes at the school the students attend. The implementing U.S. Department of Education regulations allow districts to employ public school employees in private schools. Also, private school employees can be hired by an LEA to perform services as long as the services are provided outside of their normal working hours. Once employed, they work under the supervision of public school personnel (20 C.F.R. $\S$ 200.64(b)(3)(i))). If IDEA funds are used to purchase equipment, property, or supplies, 
they can only be used in private schools for the benefit of the students with disabilities; additionally, they must be secular, neutral, and nonideological (20 U.S.C.A. $\S$ $1412(\mathrm{a})(10)(\mathrm{A})(\mathrm{vi})(\mathrm{II}))$.

\section{Provision of Services}

Students who attend private schools do not have an individual right to receive any of the services they would be entitled to if they were to attend their local public school (34 C.F.R $\$ 300.137(a)$ ). This is not to say that students are denied the right to services under IDEA; rather, public school officials have the authority to develop services plans, and choose which students from the private schools will receive services. Therefore, the responsible public agency is not required to provide a parentally placed private school student with disabilities some or all of the special education and related services that the child would receive if enrolled in a public school. This nonrequirement reflects the longstanding interpretation of the limitations of state education agencies' and LEAs' statutory obligations to make services available to the population of eligible parentally placed private school children with disabilities, in light of the limited funds that LEAs must expend on services for these children (Pacer Center, 2012).

IDEA requires LEAs to give representatives from private schools the opportunity to attend the meetings when the services plans are developed. IDEA stipulates that such sessions should provide the opportunity to engage in "timely and meaningful consultation," and public school officials have to obtain in writing confirmation from private school representatives that this, indeed, took place (34 CFR $\S 300.134(\mathrm{e}) ; 20$ U.S.C.A. $\$ 1412(\mathrm{a})(10)($ A)(iii)). 
According to 34 C.F.R. $\S 300.137$ (c), a services plan lists the service(s) the student may receive when a student attends a private school. A services plan must be developed and implemented for each private school child with a disability who has been designated by the LEA in which the private school is located to receive special education and related services. An IEP is a written statement for each child in a public school with a disability that is developed, reviewed, and revised in a meeting in accordance with 34 C.F.R. $\$ 300.320$ through 300.324 . An IEP also provides the child and the child's family with more rights and protections than a services plan (Russo et al., 2009).

When it is determined that services will be provided to a student enrolled in private school, they must be delivered by personnel who meet the same standards as the personnel who deliver services in public schools. As stated previously, the personnel can be from the LEA or the private school when working under the supervision of the LEA, which is the case even if the student is receiving lesser or different services. Because students with disabilities in private schools are not entitled to the same amount of services as they would in public school, the regulations do not require an IEP to be developed. In its place, school officials are required to develop a services plan describing the service(s) that will be made available. Services plans must be completed using a process similar to the IEP process (34 CFR $\S 300.138)$.

\section{Dispute Resolution}

IDEA requires the U.S. Secretary of Education to ensure the delivery of special education services for eligible students if state or local school officials either significantly fail to, or are unwilling to provide services. The secretary can only act on complaints once state officials have had a stated amount of time to respond to accusations that 
students were not served (34 C.F.R. § 300.136; 20 U.S.C.A. § 1412(a)(10)(A)(v)). IDEA has been litigated numerous times, but surprisingly few cases contest the delivery of special education services for students enrolled voluntarily in private schools (Russo et al., 2009).

\section{Admissions Policies for Students With Disabilities in Private Schools}

Because public schools can choose which, if any, services they will provide to students enrolled in private schools in their jurisdictions, it is important for private schools to know which students they can serve with the resources that are available to them. Many private schools do enroll students with disabilities, but there is scarce literature that shows the type of services provided to students in private schools by the LEA (Taylor, 2005). Independent schools and private religious schools vary slightly in the context of special education law.

The National Association of Independent Schools NAIS is a nonprofit membership organization. It represents more than 1,400 independent schools and associations both in the United States and abroad. An independent school is one that is not operated by, or closely affiliated with, a religious entity. The following appears on the NAIS (2006) website:

The National Association of Independent Schools (NAIS) exists to represent and sustain schools that are self-determining in mission and program, free from government control, and governed by independent boards. NAIS serves independent schools, adjusting focus as emerging issues dictate. NAIS is a hub of resources and expertise on matters relating to schools. We embrace innovation, powered by creativity; networking; and energy around valuing, sustaining, and growing independent schools. The practice of NAIS is high tech and high touch, high performance and high integrity.

According to the NAIS, federal laws including the ADA and Section 504 of the 1974 Rehabilitation Act need to be taken into consideration when dealing with admissions 
materials and interview questions. The ADA also prohibited discrimination on the basis of disability in employment. Title III of the ADA does apply to independent schools as places of public accommodation, whether or not the school receives federal funding. It prohibits exclusion, segregation, and unequal treatment for students and employees. An independent school must make "reasonable modifications" or "reasonable accommodations" to its policies and procedures to ensure equal participation in its services (42 U.S.C.A $\S 12182$ ). Some examples of reasonable accommodations include providing architectural access; providing aides and services necessary for effective communication; and modifying policies, practices, and procedures if feasible (Wright's Law, 2012).

If a private school receives federal financial assistance, Section 504 generally prohibits discrimination due to a disability in institutions that receive the federal financial assistance (29 U.S.C.A. $§ 794)$. Additionally, the school must include a "notice of nondiscrimination" in its admissions materials that the school does not discriminate on the basis of disability or handicap in "admission or access to, or treatment or employment in, its program or activity" (34 C.F.R. $\S 104.8$ ).

Independent schools must provide reasonable accommodations to students during the application process. For example, according to NAIS (2006), the school may need to provide written materials in formats that are more accessible to the student (e.g., large print, Braille, or orally). During the admissions process, the school can only inquire about information that will help to determine if the student can participate in the most essential parts of the academic program. For example, a school cannot ask about a physically apparent disability, but it can ask the applicant to identify any 
accommodations that he or she might need if accepted. However, this information cannot be used for "improper purposes that would limit the student's ability to participate in the program."

Private schools, including religious Catholic schools, are able to set baseline academic standards for admission and is not legally obligated to accept a student with a disability, who, if given reasonable accommodations, is still not academically qualified. Also, a school may deny a parent or student request for a specific accommodation. The ADA only guaranteed an individual with a disability the right to a "reasonable accommodation." What qualifies as a "reasonable accommodation" is determined on a case-by-case basis. If a requested accommodation would fundamentally modify the school or the school's programs or impose a significant burden, the accommodation would not be considered reasonable (ADA, 1990, Title III).

Catholic schools are not legally required to accept students with disabilities; however, enrolling students with disabilities is consistent with Church teaching (DeFiore, 2006). It is a complex issue because accepting students with disabilities requires Catholic schools to effectively meet the students' needs. The National Catholic Educational Association does not have an official stance on admissions policies for students with special needs, but it has been active in promoting awareness for the need for Catholic dioceses and schools to develop successful special education models. A challenge for Catholic schools with competitive academic programs and selective admissions policies is how to maintain standards of excellence while also broadening the population of students it serves. 


\section{Catholic School Law}

The law for independent schools and Catholic schools is very similar when it comes to educating students with disabilities. However, there are several distinctions because Catholic schools are considered religious organizations. Because Catholic schools espouse Catholic social teaching, they focus on the moral theology of special education more than special education law. Catholic schools strive to be inclusive toward all students not because of imposed legal obligations, but because of a preferential option for those who are marginalized in society (Scanlan, 2009). Whether determining this is true in the context of children with disabilities is one of the purposes of this dissertation.

Federal law prohibits discrimination on the basis of race, gender, disability, age or national origin. Title VII of the 1964 Civil Rights Act prohibits discrimination and retaliation for filing complaints on the basis of race, color, sex, and national origin in all aspects of public and private employment. Discrimination on the basis of religion is also prohibited; however, religious institutions may give preference to their own members when it comes to hiring employees and accepting students (Shaughnessy, 1998).

Religious schools have been the focus of litigation with regard to acceptable limits of aid under the Establishment Clause of the First Amendment. In Aguilar v. Felton (1997), the U.S. Supreme Court prohibited the onsite delivery of remedial Title 1 services in religious schools. The Court struck down a program in New York City even though there was no alleged misconduct or misuse of funds. This ruling was based on the fear that using public school officials to provide services in religious schools could have possibly created excessive entanglement between government and religion. As a result, school boards had to provide services at public schools or neutral sites; therefore, many 
students who attended religious schools were not given equal educational opportunities under Title 1 (Russo, Massucci, Osborne, \& Cattaro, 2002).

The landscape began to change several years later. In Zobrest v. Catalina Foothills School District (1993), the Court ruled that a school district in Arizona could provide the onsite delivery of the services of a sign language interpreter for a student enrolled in a Catholic high school. The Court decided that because the interpreter was merely a channel through whom information was passed, the use of a publicly funded sign language interpreter in private schools did not violate the Establishment Clause. In Agostini v. Felton (1997) 4 years later, the Court practically lifted the ban on onsite delivery of services in religiously affiliated schools in New York City as long as certain protections were in place. More recently, in Mitchell v. Helms (2000), the U.S. Supreme Court ruled on Chapter 2, now Title VI, of Title I of the Elementary and Secondary Education Act. This ruling permits the loan of state-owned instructional materials to students in private independent and religious schools that are eligible for special education services (Russo et al., 2002; Shaughnessy, 2005).

When IDEA was reauthorized in 1997, it clarified the legal obligations of public districts to provide private school students with special education services. However, this clarification and the subsequent reauthorization have failed to shed light on the delivery of special education services for students in religiously affiliated schools. It is clear that students in religious schools are entitled to receive some services, but they have funding restrictions that limit the services these students receive if school districts follow only the letter of the law and do not provide additional services (Russo et al., 2002; Shaughnessy, 
2005). The same is true if religious schools do not provide funding for additional services.

As stated previously, Section 504 applies to any school receiving federal financial assistance. It has been disputed that the amount of assistance is not legally significant; however, it would be legally irresponsible for a Catholic school to ignore its application (Russo et al., 2002). Schools can avoid compliance if a modification for a student imposes "undue financial burden" to the school, major alterations would be needed for the student to attend or, if the otherwise qualified student with a disability has the potential to create substantial risk of injury to the student or others (Russo et al., 2009).

As an antidiscrimination law, Section 504 of the Rehabilitation Act of 1974 requires schools to provide services and benefits to students with disabilities that are comparable to the services and benefits received by students who do not have disabilities. In other words, students with disabilities and those without are entitled to equal educational opportunity. But, like the ADA, Section 504 does not require additional services to serve the needs of these students that would not be provided to students without disabilities. Significantly for Catholic schools, Section 504 applies to all public and private schools that receive federal aid; although, there is a FAPE requirement for students in public schools (Scanlan, 2009). The programs should not be separate unless it is absolutely necessary for the program to be effective. The creation of separate programs to provide specific services to address learning disabilities is not the most effective way of educating students with learning disabilities. By contrast, an integrated approach considers how various factors (e.g., teacher placement, professional 
development, scheduling, and student grouping) can work in collaboration to create a school community where all members are integrated (Scanlan, 2009).

\section{Research on Catholic Schools and Students With Disabilities}

There is a slowly growing call for more research in the area of students in religious schools and special education services (Taylor, 2005). The United States Conference of Catholic Bishops (USCCB, 2002) published a report titled Catholic School Children With Disabilities, which sought to determine the the extent to which children with diagnosed learning disabilities are present in Catholic schools and the manner and degree to which Catholic school students with disabilities receive special education and related services. Additionally, the effectiveness of the child find process for Catholic school students under IDEA statute, regulations, and guidance was examined. Under IDEA, child find processes entail public schools actively seeking out school-age persons who need support services, and acting affirmatively to provide the necessary services for the student to participate in education (Mawdsley, 2000).

A study conducted by USCCB in 2002 (prior to the 2004 amendments) found that students with disabilities attend Catholic schools; $7 \%$ of students in Catholic schools have been diagnosed as having a disability (compared to more than $11 \%$ in public schools), and less than $1 \%$ of the identified students receive services funded by IDEA. Although most of these students have learning or speech and language disabilities, $28 \%$ have less common conditions such as mental retardation, hearing and vision impairment, autism, physical disabilities, emotional and behavioral disorders, or traumatic brain injury. The specific data from the study are presented in Table 1, along with comparative data from the U.S. Department of Education. It is important to note that the USCCB data were 
collected in 2002 and the Department of Education data in 2006-2007. Thus, the data are not directly compatible.

Table 1

Students With Identified Disabilities Enrolled in Catholic and Public Schools

\begin{tabular}{lccc}
\hline Disability & $\begin{array}{l}\text { Percentage of } \\
\text { children with } \\
\text { disabilities in } \\
\text { Catholic schools }\end{array}$ & $\begin{array}{l}\text { Percentage of } \\
\text { total enrollment } \\
\text { in Catholic } \\
\text { schools }\end{array}$ & $\begin{array}{l}\text { Percentage of } \\
\text { total enrollment } \\
\text { in public } \\
\text { schools }\end{array}$ \\
\hline Data collection year(s) & 2000 & 2000 & $2006-2007$ \\
Mental retardation & 1.16 & 0.08 & 1.1 \\
Hearing impairment or deafness & 2.00 & 0.14 & 0.2 \\
Orthopedic & 1.05 & 0.07 & 0.1 \\
Autism & 0.75 & 0.05 & 0.5 \\
Emotional disturbance & 3.03 & 0.21 & 0.9 \\
Developmentally delayed (ages & 3.43 & 0.23 & 0.7 \\
3-9) & & & 3.0 \\
Speech/language & 26.93 & 1.84 & 0.1 \\
Uncorrected vision impairment & 2.10 & 0.14 & 5.4 \\
Learning disability & 44.71 & 3.05 & 13.3 \\
Deaf and blind & 0.67 & 0.05 & Rounds to 0 \\
Traumatic brain injury & 0.40 & 0.03 & 0.1 \\
Other health impairments & 13.78 & 0.94 & 1.2 \\
Total & 100 & 6.83 & $\begin{array}{l}13 \\
\text { Note. Data are based on the }\end{array}$ \\
\hline
\end{tabular}

Note. Data are based on the total enrollment in schools; pre-kindergarten through 12th grade. No data were available for students enrolled in independent schools. Adapted from Catholic School Children With Disabilities by United States Conference of Catholic Bishops, 2002, Washington, DC: Author; and Digest of Educational Statistics, 2008 (NCES 2009-020) by the U.S. Department of Education, National Center for Education Statistics, 2009, retrieved from http://nces.ed.gov/pubs2009/2009020.pdf

It is significant to note the high percentage of children enrolled in Catholic schools with speech/language disabilities $(26 \%)$, learning disabilities $(44 \%)$, and other health impairments (13\%). Although the percentages are high, the percent of total 
enrollment of identified students in Catholic school is very low. The percentage of identified students in public schools is almost double (13.3\%) the percentage of students in Catholic schools $(6.83 \%)$. In the study, $87 \%$ of the dioceses reported that some of their schools are unable to accept students with significant special needs because they do not have services available to meet the needs of the students. This number does not include the parents who called to inquire about enrollment, but did not complete the process.

Another finding of the USCCB (2002) study describes the child find process as "fragmented at best" (p.8). The written law was clear, but the interpretation of the process at the local level often deviated from federal law because the LEA has flexibility when determining the child find activities it will conduct. The inconsistency with the child find process may mean that more students enrolled in Catholic schools have disabilities than are actually accounted for in Table 1, but they are currently unidentified.

When the child find process is effective, and the child is determined to have a disability, obtaining services for the child with special needs is difficult. The USCCB (2002) study found that only $13 \%$ of the cost of special education and related services for Catholic school students with disabilities is funded by IDEA. The schools pay an additional $34 \%$ of the cost, and the rest is presumably paid for by the families directly. In effect, neither the child find nor the service provision sections of IDEA appear to be working for Catholic and/or private school students with special needs.

The USCCB (2002) study also found that Catholic school children who were identified and/or referred and accepted for testing are less likely to be diagnosed with a disability by a public school evaluator than by a private evaluator. One can speculate that 
there is financial disadvantage for public evaluators to diagnose students, and potential financial advantage for independent private evaluators to diagnose students. Public and private evaluators reported that they used the same most common testing instruments, so test variation does not appear to be an issue. Additionally, the majority of the cost of providing special education services in Catholic schools is provided by parents and/or supported by school tuition. Thirty-four percent of all services provided to students with disabilities are supported by tuition. Other results from the same study include the following: Catholic school students who are diagnosed with a disability are not receiving sufficient services through IDEA, and the responsibility for accommodating the special needs largely rests on the Catholic school administrators and teachers.

\section{The Need for Legislative Reform}

IDEA has failed to create an individual entitlement to programs and services for students enrolled in private schools. It has also failed to ensure that services correspond to student needs and to make sure that the services will be delivered onsite at the private school. Under federal law, there is a lack of clear criteria for LEAs to apply when making decisions regarding these students. Currently, LEAs have complete discretion when assigning IDEA benefits, and statutory remedies for failing to meet child find and service delivery obligations are nebulous (Wasserman, 2009).

The USCCB (2002) study was critical of the quality of implementation of the law at that time. Although public school districts have the obligation to locate, identify, and evaluate children suspected of having a disability, Catholic school parents and staff have continued to report difficulty in accessing these services. They stated, "The implementation of the (child find) process for children in Catholic schools is fragmented 
at best and 'inhospitable' to children with disabilities whose parents chose to enroll them in Catholic schools" (USCCB, 2002, pp. 12-13).

Wasserman (2009) suggested three proposals wherein state legislative enactments could provide benefits to students enrolled in private schools. First, states could define "appropriateness" as more than just a basic floor of opportunity. Such an entitlement could result in students receiving services in greater frequency, duration, and/or intensity than is currently required by IDEA. Second, state laws could create an entitlement to a wider range of programs and services than mandated by IDEA. This entitlement could provide for programs and services that are not included in IDEA's definition of special education. Third, state laws could require that services be provided onsite at private schools. Currently, students who are offered services most likely need to go offsite if their parents choose to receive them, and only occasionally is transportation provided.

Supporters of increased rights to students parentally placed in private schools could demand that programs for private school students be comparable to those offered to students enrolled in public schools. This would require that state standards of appropriateness exceed the standards set forth in IDEA. Wasserman (2009) argued that to remain fair to all students, the cost of comparable programs should not exceed the cost incurred if the child were to attend a public school.

IDEA could be amended to provide students enrolled in private schools an individual entitlement to comparable programs. This amendment would also mean that students in private schools would receive IEPs rather than services plans, which are less specific and hold less weight. Because parents who pay to have their children enrolled in private schools already pay the cost of tuition for the students' general education, LEAs 
are relieved of that cost. LEAs also benefit from the taxes that parents of private school students pay that help finance public schools. Thus, there is a financial incentive for LEAs to deliver comparable programs and services in private schools to avoid students returning to public schools.

\section{Rationale}

The USCCB (2002) stated, "Parentally placed private school children have been an invisible group of children. This must change" (p. 6). They also believed it necessary for alterations to IDEA that will make some fundamental changes to ensure that all students with disabilities attending a Catholic or other private school receive equitable services as their public school counterparts. If students with special needs transferred to public schools, districts would be paying for both their special and general educations but also receiving IDEA funding.

Even though IDEA was reauthorized in 2004, the basic categories of eligibility under the law did not change. There are still two classes of students - children whose parents enroll them in public schools and children whose parents enroll them in private schools. Students with disabilities are entitled to the same educational experience as their peers without disabilities. Basically, the children in public school are entitled to special education and related services provided at public expense-without additional charge to the parents. The IEP specifically states that children will be served in the least restrictive environment (Wright's Law, 2012). In short, this is an individual entitlement under the law to a program that is meant to meet the documented needs of children.

Conversely, the parentally placed child enrolled in a private school may or may not receive special education and other related services even if the student would qualify 
for such services. This depends upon the determination of eligibility through the child find process, the LEA's decision on how to allocate the proportionate amount of IDEA funds to private school students, and the private schools' willingness to recognize and provide services for students with disabilities. The students are entitled to their share of IDEA funds through services provided by public schools, but there is no individual entitlement. Therefore, IDEA treats private school students with special needs the same way it did before the 2004 reauthorization. Parents of children with special needs potentially face a tough choice: Enroll in a private school and risk losing essential rights and services for their children or enroll in public school, thus retaining the right to individual entitlement (DeFiore, 2006).

Finally, in an open letter to then U.S. Secretary of Education Rod Paige, representatives from private religious and nonreligious schools including the presidents from the NAIS and the National Catholic Educational Association outlined the revisions they would like to see take place when IDEA was reauthorized in 2004. In the letter, the writers contended, "special education services should be an entitlement to children with disabilities, regardless of where they go to school. Currently, private school children do not have an entitlement for services, not because their disability does not warrant it, but simply because they are being educated outside of the public school system." Advocates for private schools believe it is time for legislative reform to provide comparable programs and services to students who are not given access to a free and appropriate education. 


\section{CHAPTER THREE \\ METHODOLOGY \\ Participant Selection}

I chose schools located in the SDUSD district because it is the eighth largest school district by enrollment in the country and the second largest district in California. Thus, there may be some similarity in the special education context to other urban districts. Furthermore, I have a sample of convenience, being a Catholic school administrator in this district.

It is important to note that other evidence suggests that Catholic schools do not always exhibit practices and policies reflective of social justice education, particularly when it comes to creating effective service delivery models for students with special needs and English language learners (Weaver \& Landers, 2000). The values of Catholic social teaching, emphasizing human dignity, the common good, and preferential options for the marginalized, compel LEAs to work together with Catholic dioceses to design service delivery that is inclusive and avoids exclusionary practices.

The Diocese of San Diego encompasses 45 elementary and middle schools (two closed at the completion of the 2011-2012 school year) and five high schools located in various school districts in San Diego County. The schools are extremely diverse in terms of financial solvency, population, class size, instructional methods, and philosophies. The one significant common criterion is their commitment to a strong Catholic identity.

Of the 45 schools, 19 are located within the boundaries of SDUSD. The sample size is restricted to 19 simply because there are only 19 Catholic schools within the boundaries of SDUSD. The other schools in the Diocese are spread out among dozens of 
other school districts. It would be difficult to glean an accurate picture of each school district given that, in many instances, only one to two diocesan schools are located within their boundaries. All 19 principals from the Catholic schools located within the boundaries of SDUSD were surveyed in order to collect information on the entire population of Catholic schools within this specific district. They had the option of forwarding the survey to another staff member who might be more knowledgeable on IDEA and child find. The instructions on the survey indicated that only one survey per school site was to be completed. The principals ranged in years of administrative experience—anywhere from first year principals to seasoned principals. The Diocese's associate director of schools notified the 19 principals that an electronic survey would be emailed to them, encouraging them to complete it in a timely manner.

\section{Data Collection Procedures}

For the purpose of this study, two forms of data were collected: survey data and interviews.

\section{Survey}

The cross-sectional survey consisted of 14 items - both multiple choice and checkbox. There was additional room for comments after each of the multiple-choice questions as well as a general comments section at the end The survey was created on Wufoo, which was recently acquired by Survey Monkey. It was sent out in May of 2013 and data were collected by the end of the month. The Diocese's associate director sent out reminders to principals until a majority of the 19 surveys were completed.

The questions were designed to determine each principal's knowledge of child find and the principals' general familiarity with IDEA. Because the principals are the 
school's instructional leaders, it is necessary for them to have knowledge of the current laws in special education in order to best meet the needs of their students.

The multiple-choice questions on the survey consisted of Likert items. The choice options on the scale were static throughout the survey: Strongly Agree, Agree, Disagree, Strongly Disagree, and Don't Know. The range captured the intensity of the respondents' feelings for each item. The scale was balanced with an equal number of positive and negative choices. This survey was designed to be useful in determining the familiarity administrators in the Diocese have with IDEA and child find. Boxes for comments were available for additional feedback.

\section{Interviews}

In order to add clarity and depth to the survey item responses, a semistructured interview protocol was developed. Five out of the 14 survey respondents indicated they would be willing to participate in a follow-up semistructured interview. A semistructured interview is defined as "an interview with the purpose of obtaining descriptions of the life world of the interviewee in order to interpret the meaning of the described phenomena" (Kvale \& Brinkmann, 2009, p. 3). Kvale and Brinkmann (2009) described the seven stages of the research interview:

1. Thematizing an interview: Clarifying the why and what of the interview.

2. Designing: Planning the procedures and techniques of the interview study.

3. Interviewing: Conducting the interview and using a format based upon the interview purpose and content.

4. Transcribing: Analyzing the interview data by transforming the interview from its oral form to a written form. 
5. Analyzing: Determining the purpose of the interview and the appropriate steps and methods of analysis.

6. Verifying: Determining the validity, reliability, and generalizability of the interview data.

7. Reporting: Detailing the findings of the interview and the methods used in an ethical manner.

I used these seven steps of the interview research process in order to organize the interviews. When thematizing, one must clarify the purpose of the study, gain knowledge of the subject matter of the investigation prior to the interviews, and the researcher needs to become familiar with a variety of interview techniques (Kvale \& Brinkmann, 2009).

Five interviews were conducted with administrators who indicated they would be willing to participate in a brief follow-up interview. Four of the interviewees were principals at Catholic elementary and middle schools. Only one interviewee was an administrator from a Catholic high school. These interviews were all conducted in locations selected by the participants. The interview protocol consisted of 18 questions separated into three major categories: interviewee background, institutional perspective, and a follow-up portion to survey responses. The interviews ranged from 15 minutes to one hour in length. I kept field notes during the interviews, noting to record questions I wanted to explore further with the participants. I also noted when the participant had a visceral reaction to survey questions and/or probes (e.g., laughter, eye rolling, discomfort). 


\section{Survey Analysis}

All data were analyzed using Wufoo tools and Excel. Descriptive statistics, specifically summary statistics and graphs, were utilized. Each item was analyzed separately and some categories of questions were summed (e.g., the questions relating to knowledge of the child find process). Data are displayed in pie charts in Chapter 4.

\section{Interview Analysis}

In order to prepare data for the coding process, it was required that all interviews be transcribed (Merriam, 1998; Patton \& Patton, 1990). For the analysis of the participant interviews, the first cycle coding processes of in vivo and values coding were used to note "participant language, perspectives, and worldviews" (Saldana, 2009, p. 48). Saldana (2009) noted that in vivo codes are based on "impacting nouns, action-oriented verbs, evocative word choices, clever or ironic phrases, similes, and metaphors" (p. 75) that demonstrate a person's perspective. Similarly, values coding is the "application of codes onto qualitative data that reflect a participant's values, attitudes, and beliefs, representing his or her perspectives or worldview" (Saldana, 2009, p. 89). Because this study was looking at school leaders' insights and perspectives on child find and Catholic school students, the use of in vivo and values codes enabled a greater depth of analysis.

The second cycle of coding took place at the end of the first cycle. Saldana (2009) stated the primary goal of second cycle coding is "to develop a sense of categorical, thematic, conceptual, and/or theoretical organization" (p. 149). Additionally, second cycle codes "literally and metaphorically constantly compare, reorganize, or 'focus' the codes into categories, prioritize them to develop 'axis' categories around which others revolve" (Saldana, 2009, p. 42). Pattern coding was utilized for the second 
round to "help develop the 'metacode' - the category label that identifies similarly coded data" (Saldana, 2009, p. 150). Saldana stated that pattern coding is used "to develop a statement that describes a major theme, a pattern of action, a network of interrelationships, or a theoretical construct from the data" (p. 154). Creswell (2007) termed this process of building patterns, categories, and themes from the bottom up as inductive data analysis (p. 175).

Through several rounds of coding, a pattern of analyses was created to bring all collected data into the leading findings for this study. For the analysis of the participant interviews, the first cycle coding processes of in vivo and values coding were used to note "participant language, perspectives, and worldviews" (Saldana, 2009, p. 48). Because this study was looking at school leaders' insights and perspectives on child find and Catholic school students, the use of in vivo and values codes enabled a greater depth of analysis.

\section{Methodological Limitations of the Study}

This research study was conducted in the spring of the 2012-2013 school year; however, administrators based their responses solely on the 2012-2013 school year. The study does not reflect any changes in diocesan or district policy after data were collected. Additionally, because this research is rooted in a legal framework that is dynamic, it is not possible to control for any legislation that may change. Research on special education for private school students is needed for the possibility of effecting legislative change in special education policies for students parentally enrolled in private schools.

This study only included Catholic schools within the SDUSD boundaries, which is another delimitation. Additionally, the sample size was restricted to 19 respondents. 
The ability to generalize to other regions and other private schools is limited. But, the data should be useful in moving the Diocese of San Diego forward in consultation processes with the public school system. Additionally, as Merriam (1998) stated, "A small sample is selected precisely because the researcher wishes to understand the particular in depth, not to find out what is generally true of the many."

Because some respondents may be familiar with the processes, but not familiar with the terminology, survey questions were worded more generally. For example, the term local education agency was phrased as "local public schools." The legal terminology was used sparingly so as not to confuse respondents. 


\section{CHAPTER FOUR}

\section{FINDINGS}

The purpose of this study was to better understand the efficacy of the child find process in educating Catholic school representatives. I also wanted to learn what strategies SDUSD employs to make Catholic school representatives aware of the process. If administrators are not knowledgeable of the child find process, it makes it highly unlikely that they could advocate for their students who have suspected disabilities (Scanlan, 2009). This study also aimed to determine the extent to which students with disabilities are enrolled in Catholic schools within the boundaries of SDUSU.

Schools located within SDUSD boundaries district were chosen because it is the eighth largest school district by enrollment in the country and the second largest district in California. Thus, there may be some similarity in the special education context to other urban districts.

The focus on Catholic schools in the study, and not nonreligious private schools, was intentional. In the field of education, Catholic schools can serve as a strong role in social justice education. Although the larger field of education as a whole pursues social justice by attempting to ameliorate marginalization in schools, there are several factors that make Catholic schools unique such as the pursuit of social justice and the tendency to have a more heterogeneous environment than nonreligious private schools.

The research was guided by the following questions:

1. How knowledgeable are Catholic school administrators on the child find process?

2. What strategies does SDUSD use to make them aware of the process? 
3. To what extent are children with disabilities enrolled in Catholic schools within the Diocese of San Diego?

4. Given the Individuals with Disabilities Education Act (IDEA) 2004 regulations, how does the child find process operate for parentally placed Catholic school children who may have a disability?

5. How and to what extent do Catholic school students with disabilities receive special education and related services through IDEA 2004?

Table 2 summarizes the descriptive statistics for the Research Questions that were answered with survey data. 
Table 2

Descriptive Statistics for the Research Questions

\begin{tabular}{|c|c|c|c|}
\hline Research Question & Mean & Range & Percentage \\
\hline $\begin{array}{l}\text { Self-reported } \\
\text { administrator } \\
\text { knowledge on child } \\
\text { find }\end{array}$ & $\mathrm{SQ}-4 M=1$ & $\begin{array}{l}\text { Strongly agree to } \\
\text { strongly disagree }\end{array}$ & $\begin{aligned}+2 & =22 \% \\
+1 & =43 \% \\
+0 & =0 \% \\
-1 & =21 \% \\
-2 & =14 \%\end{aligned}$ \\
\hline $\begin{array}{l}\text { Child find process } \\
\text { (identifying and } \\
\text { locating) }\end{array}$ & $\mathrm{SQ}-5 M=0.2$ & $\begin{array}{l}\text { Strongly agree to } \\
\text { strongly disagree }\end{array}$ & $\begin{aligned}+2 & =7 \% \\
+1 & =36 \% \\
+0 & =21 \% \\
-1 & =29 \% \\
-2 & =7 \%\end{aligned}$ \\
\hline $\begin{array}{l}\text { Child find process } \\
\text { (parent signed } \\
\text { assessment) }\end{array}$ & $\mathrm{SQ}-7 M=-.02$ & $\begin{array}{l}\text { Strongly agree to } \\
\text { disagree }\end{array}$ & $\begin{aligned}+2 & =7 \% \\
+1 & =36 \% \\
+0 & =43 \% \\
-1 & =36 \% \\
-2 & =0 \%\end{aligned}$ \\
\hline $\begin{array}{l}\text { Child find process } \\
\text { (evaluating) }\end{array}$ & $\mathrm{SQ}-6 M=1.8$ & $\begin{array}{l}\text { Strongly agree to } \\
\text { disagree }\end{array}$ & $\begin{aligned}+2 & =14 \% \\
+1 & =14 \% \\
+0 & =22 \% \\
-1 & =14 \% \\
-2 & =0 \%\end{aligned}$ \\
\hline $\begin{array}{l}\text { Child find process } \\
\text { (timeline) }\end{array}$ & $\mathrm{SQ}-8 M=-1$ & $\begin{array}{l}\text { Strongly agree to } \\
\text { disagree }\end{array}$ & $\begin{aligned}+2 & =7 \% \\
+1 & =14 \% \\
+0 & =43 \% \\
-1 & =36 \% \\
-2 & =0 \%\end{aligned}$ \\
\hline $\begin{array}{l}\text { IDEA services on } \\
\text { Catholic school site }\end{array}$ & $\mathrm{SQ}-12 M=-3.8$ & $\begin{array}{l}\text { Agree to strongly } \\
\text { disagree }\end{array}$ & $\begin{aligned}+2 & =0 \% \\
+1 & =7 \% \\
+0 & =7 \% \\
-1 & =29 \% \\
-2 & =57 \%\end{aligned}$ \\
\hline $\begin{array}{l}\text { Students counted } \\
\text { for IDEA purposes }\end{array}$ & $\mathrm{SQ}-11 M=$ & $\begin{array}{l}\text { Agree to strongly } \\
\text { disagree }\end{array}$ & $\begin{aligned}+2 & =0 \% \\
+1 & =28 \% \\
+0 & =36 \% \\
-1 & =29 \% \\
-2 & =7 \%\end{aligned}$ \\
\hline
\end{tabular}

Note. Answers ranged from Strongly Agree $=+2$ to Strongly Disagree $=-2 ; 0=$ Don't Know. Research Question 2 was answered expressly through interview data and Research Question 3 data are reported in a table below. 


\section{Research Question 1}

Research Question 1: "How knowledgeable are Catholic school administrators on the child find process?"

In this section, I present the results of the survey and interview data to determine how knowledgeable Catholic school administrators are on the child find process. This question was directly answered by Survey Question Number 4: "For the following statement, indicate the degree to which you agree/disagree. 'I know how the public school special education process (i.e., the child find process) works for students enrolled in my school who are suspected of having a disability." The results to this question varied, and answers ranged from strongly agree to strongly disagree and a mean of 1 , with $65 \%$ of respondents indicating that they agree $(+1)$ or strongly agree $(+2)$ that they are knowledgeable of the process, and 35\% indicated that they were not knowledgeable by selecting disagree $(-1)$ or strongly disagree $(-2$; see data in Figure 1$)$.

I know how the public school special education process (i.e., the Child Find process) works for students enrolled in my school who are suspected of having a disability.

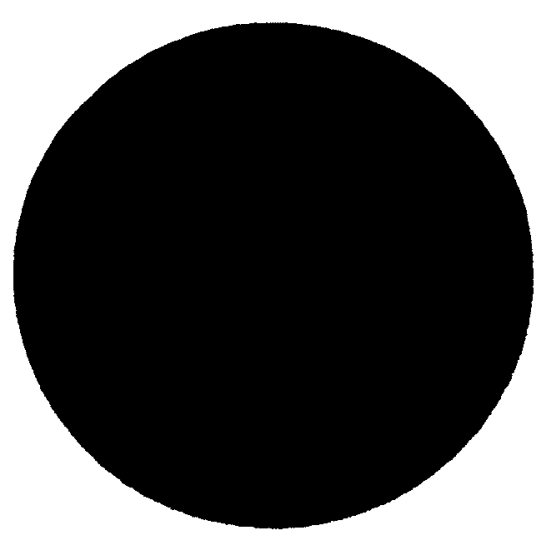

- Strongly Agree +2

- Agree +1

a Don't Know 0

- Disagree -1

- Strongly Disagree -2

Figure 1. Survey Question 4 
However, this question was also addressed indirectly through other survey questions and interview data. For example, several of the respondents who indicated that they agreed $(+1)$ or strongly agreed $(+2)$ with the statement above, also indicated that they did not know the response to Survey Question Number 11 (Research Question 1): "All students in my school who were identified through the public school system were counted for the purpose of generating IDEA services." This response indicates that there may be a discrepancy between what they think they know and the extent of their actual knowledge. Furthermore, interview data contradict the findings of the survey as it relates to this research question. Only one out of the five interviewees was able to clearly articulate the process.

\section{Research Question 2}

Research Question 2: "What strategies does SDUSD use to make them (administrators) aware of the process (i.e., child find)?" This research question was addressed indirectly through survey data and explored more deeply through follow-up interviews with administrators. The strategies that are reported on the Parentally Placed Private School tab on the public SDUSD website for parents and private school personnel were not the focus of this research question. I was looking to see which strategies the administrators reported having knowledge of and then comparing them to the strategies that SDUSD reports.

Survey Question Number 4 was related to this research question. It stated: "I know how the public school special education process (i.e., child find process) works for students enrolled in my school who are suspected of having a disability." In follow-up interviews, I asked respondents who strongly agreed or agreed on the survey with the 
statement how they became familiar with the process. One administrator, Tim, who has been a principal at a number of schools in the Diocese of San Diego, credited the personnel at the Parentally Placed Private School office for being proactive. Although, it became clear during the interview that this particular administrator took much of the initiative by creating relationships with key contacts, and he was able to access resources for his students. He stated,

I give a lot of credit to the private school office out of the district [Parentally Placed Private School office], and I've gotten to have a working relationship with them. I can pick up the phone and say, 'You know what, we're having this issue, is there anything you can do to help us etc.' I formed a strong relationship with David [SDUSD PPPS Representative], so if I did call and leave a message it wasn't like some guy out of the blue who he had no idea who I was. So we've had a good working relationship.

Conversely, I followed up with administrators who disagreed or strongly

disagreed with Survey Question 4. One administrator, Erica, a principal with 2 years of experience, disagreed with the statement that she knows how the child find process works, sharing her frustration with the perceived lack of guidance from the public school district:

I don't know how the public school does it. I only know how we do it, and it starts with the first grading period when you know how the child struggles. It's always been us as the Catholic school, seeking information and finding out what we need to do. Every child is different, so you really have to do a lot of digging on your own and until you start that process, you're kind of in the dark.

David Conner, from the Parentally Placed Private School Division, shared the strategies that his division employs.

We contact administrators multiple times per year. We send out a contact at the beginning of the year that is specific to the child find purpose, as well as sending a follow up to our annual admin meeting, that happens in February. It includes all of the information from the meeting, as well as a specific Child Find request. The Make it-Take it workshops and annual admin meeting in February serve a different purpose, but we use them to get the Child Find message out as well. It ends up being a message that we send approximately 5 to 7 times per year, in 
different formats and contexts, depending on our opportunities. We try to take advantage of as many as possible.

Administrators may be too overwhelmed to participate or somehow unaware of the scheduled meetings. Alternatively, it could be that the meetings are not being viewed as a priority in the grand scheme of principal duties. David shared that his division would prefer getting more response to his communications than they do, because he assumes that students with learning disabilities are present, to some extent, in all private schools. He views administrator initiative as vital to the process. David shared his thoughts on proactive administrators: "We definitely feel that the administrators who are proactive get more support from us, but only because we do not know the needs of the others. Sometimes that support comes in identifying students for Special Ed."

\section{Research Question 3}

Research Question 3: "To what extent are children with disabilities enrolled in Catholic schools within the Diocese of San Diego within the boundaries of the San Diego Unified School District?"

Survey Question Number 2 addressed this question directly by asking respondents to indicate if their school enrolls at least one student with a disability listed below. As presented in the table below, 12 out of the 14 school administrators reported having at least one student enrolled with a specific learning disability. Students with speech and language impairments were enrolled in at least nine of the schools. Seven of the schools enrolled students with other health or vision impairments. Six administrators reported having students enrolled with an autism spectrum disorder. Between three to five school administrators reported having students at that school with at least one of the following: hearing impairment, multiple disabilities, emotional disturbance, developmental delays, 
or an orthopedic impairment. For traumatic brain injury, deaf-blindness, or other. One school administrator reported enrolling at least one student for each of the disabilities. It is worth noting that two school administrators reported not enrolling any students with a specific learning disability such as dyslexia (see data in Table 2).

Table 3

Administrators Reporting One or More Students Enrolled With Learning Disabilities

Learning disability by type Frequency reported (Max of 14)

Specific learning disability

Speech and Language Impairment

Other health impairment

Vision impairment 7

Autism spectrum 6

Hearing impairment 5

Multiple disabilities

4

Emotional disturbance 4

Developmental delays 3

Orthopedic impairment 3

Traumatic brain injury 1

Deaf-blindness

1

Other

1

It is significant to note that the survey question did not ask them to report based on the formal documentation of the disability. This was intentional, because I predicted that busy administrators would be less likely to answer the question if I had asked them to 
retrieve and analyze student files if they did not have a current accurate count readily accessible.

To add greater depth of understanding of why students with disabilities may or may not be enrolled in each Catholic school, I asked two questions directly related to this during the follow-up interviews. First, I asked each administrator about her or his school's philosophy on educating students with disabilities. All interviewees expressed a commitment to educating students of families who want a Catholic education. However, several respondents spoke to some of the hesitancy they faced in terms of meeting the needs of each child. One experienced diocesan administrator shared their collective sentiments:

My approach to it [educating students with special needs] was that I don't want to take a student and say we can help them, if I know down deep that we can't. Even though we might have small classes and aides in the classrooms, the fact of the matter is that there would be some that we just wouldn't be able to deal with.

Several of the administrators spoke of private sources that were donated to assist in meeting the needs of students. One administrator, Tim, discussed free tutoring by community volunteers that was offered after school. Nathan, a principal of a school with very limited financial resources, mentioned the benefits of a relationship he had formed with the University of San Diego, and specifically, the Dean of the School of Leadership and Education Sciences. The Dean provided the administrator with access to her staff resources, including counselors, tutors, and development coordinators. He attributed these relationships as adding to the inclusivity of his school site; otherwise, some of these students would not be able to keep up with the academic demands of his school. He also noted that USD provides counseling resources to help meet students' emotional needs. 
He stated, "She [the counselor] basically comes to our school 4 days a week for free and does counseling... It's great because that's something we would never be able to afford."

I asked a follow-up question during the interview about consideration that may be taken in terms of enrolling students who have special needs. All of the interviewees commented on the importance of transparency from the parents during the admissions process. One administrator lamented,

The biggest issue is that the parents [need to be] up front and honest with us. [We would want them to] give us a copy of the report, and if there's medication involved, tell us. My feeling is that they [parents] just want to get them into a Catholic school and after a student has been here, the teacher would come and say, "Well, there's just something not right," and then we would contact the parent and they'd say, 'Yeah, by the way..." Why didn't you tell us?

The one high school administrator, Jennifer, whom I interviewed, spoke to the high standards of her Catholic school, and the expectations for graduates. "Our philosophy is to meet those needs as much as we possibly can while still maintaining the same expectations of learning, which is why we say that we accommodate, but don't modify." She echoed the concerns that all of the administrators shared in terms of effectively meeting the needs of students: "We just want to make sure that we can offer the resources they need to be successful at the level of academics that our school is offering."

\section{Research Question 4}

This research question was answered through the survey data and further explored in the follow-up interviews. Research Question 4: "Given IDEA 2004 regulations, how does the child find process operate for parentally placed Catholic school children who may have a disability?" 
Most of the survey questions addressed this research question so I could fully explore how the administrators viewed the efficacy of the child find process. Although the entire survey addresses child find, four questions directly addressed the process as outlined in IDEA.

The first of these was Survey Question Number 5, which stated, "The local public schools (legally referred to as the LEA) follow the child find process of identifying and locating students suspected of having a disability at my school." The results are displayed in Figure 2.

The local public schools (legally referred to as the LEA) follow the Child Find process of identifying and locating students suspected of having a disability at my school.

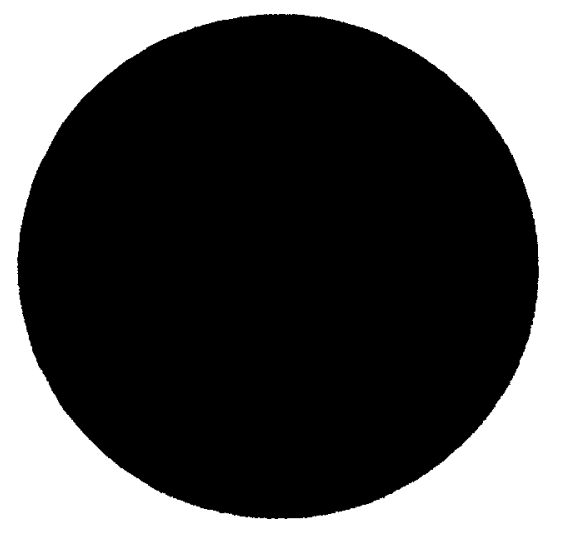

- Strongly Agree +2

- Agree +1

- Don't Know 0

- Disagree -1

- Strongly Disagree -2

Figure 2. Survey Question 5

Thirty-six percent indicated they disagreed or strongly disagreed with the statement that the LEA is locating and identifying students at their school sites. Fortythree percent of the respondents indicated they either agreed or strongly agreed with this statement. The mean response was 0.2 , and results ranged from strong agreement to strong disagreement. One survey respondent who agreed with the statement wrote in the optional comment box underneath the question: "It takes a little persistency, but it 
happens." Another administrator attributed the identification of students to the individual student's parents: "Not locating, but identifying once parents seek assistance."

All of the administrators who agreed to be interviewed disagreed or strongly disagreed with Survey Question 5. To add greater depth to this research question, in follow-up interviews, I asked interviewees to clarify why they disagreed or strongly disagreed with the survey question. Nathan, the principal at the school with very limited resources, reflected on the perceived lack of initiative by the public school district in identifying students at his site with suspected disabilities. His comments also reflect his uncertainty in his knowledge of the child find process:

I don't think they make an effort to come out and find them, and generally we have to ask...our process is we ask the kids to go to the local public schools to try to set up testing, because we don't have the ability to do that on site, so if we want to get an IEP [sic] $]^{2}$ set up for the kid, that's the process. So we send them back to the local...I think the policy is to send them back to the public school closest to where you're located; that's what I was told. So we send them to -.-- Elementary, which is right across the street. It takes forever!

In agreement, Erica, the new principal, summed up her experience by succinctly stating, "The public schools make no attempt to identify and locate students who may have special needs."

The second survey question that pertains to this research question was Number 7 , which asked if administrators report that the child find process begins immediately after the parent signs the Parentally Placed Private School assessment form. Data are displayed in Figure 3.

${ }^{2}$ Note: The term for this plan when offered in private schools is Individual Services Plan (ISP) not IEP. 
The Child Find Process for identifying students in my school with suspected disabilities begins immediately after the parent-signed assessment form is submitted to the local public school.

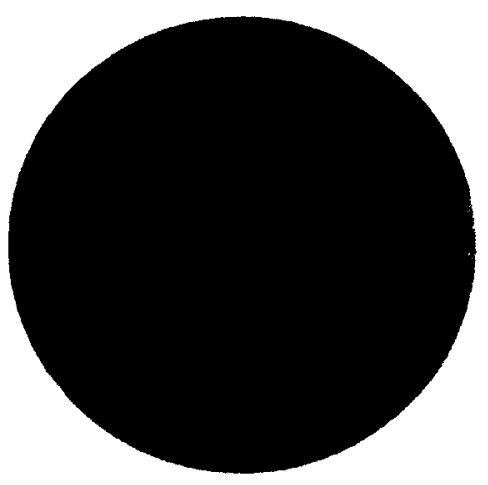

- Strongly Agree +2

- Agree +1

- Don't Know 0

Disagree - 1

- Strongly Disagree -2

Figure 3. Survey Question 7

Forty-three percent of the respondents indicated that they did not know if this was occurring. Thirty-six percent disagreed with the statement and only $21 \%$ agreed or strongly agreed that the child find process begins immediately after the parent signs the Parentally Placed Private School assessment form. The mean was -0.2 and responses ranged from strongly agree to disagree. One administrator who agreed $(+1)$ with Survey Question 5 reported in the optional comment box in the survey that the process does "Not always [begin immediate after the parent signs the PPPS request form], sometimes we need to push the issue." Another, who disagreed (-1), commented on the long duration of the process: "This is a slow-moving process. I encourage parents to act as early as possible so that their student can hope to complete the process before the year ends."

In follow-up interviews, administrators explained varied experiences with the start of the child find process. Tim, who has worked as an administrator at several schools in the diocese, disagreed with the statement and explains this discrepancy:

Every public school deals differently... when I was at ---, those public schools were like "Not us." When I was at -..., we did a lot of things privately as opposed 
to going through the district because the parents had the means to pay for it. Here, we have a lot of parents who want to go through the system because they can't afford to go private. The other thing we have here is a lot of military families, so they can go through the military...options available for military families. So, there's no hard and fast rule as to what happens, how it happens, when it happens.

He went on to explain the frustration he experiences with the perceived lack of consistency when it comes to the district's adherence to the timeline:

We were given the parameters yesterday... within 15 days this will happen, within 60 days this will happen. You know, I've heard that so many times and it just never happens all the time. So what I've come to learn is that if it doesn't happen, I just pick up the phone and call and say, you know, 'This isn't getting done, this parent has been waiting 80 days, this hasn't happened.' The interesting thing is that even if [PPPS representative] or somebody from his office would call the school, there's no guarantee they're going to follow through. But, generally, at least they know that somebody is making the call and somebody's looking at it. So, they don't necessarily want somebody to call the district and say, 'Hey, you know what, these guys aren't doing their due diligence and they've got to get on the ball.'

The high school administrator, Jennifer, reported a lack of necessity to be knowledgeable about the child find process, "Usually by the time a student comes into our school, they've already gone through the process. By ninth grade, their learning needs should have already been identified, so it's not something very often that we have to start."

Survey Question 6, which addresses Research Question 4 was related to the "evaluating" portion of child find. Administrators reported whether or not they agreed that this was taking place at their school sites. The data are displayed in Figure 4. 
The local public schools (legally referred to as the LEA) follow the Child Find process of evaluating students suspected of having a disability at my school (once parental consent is given).

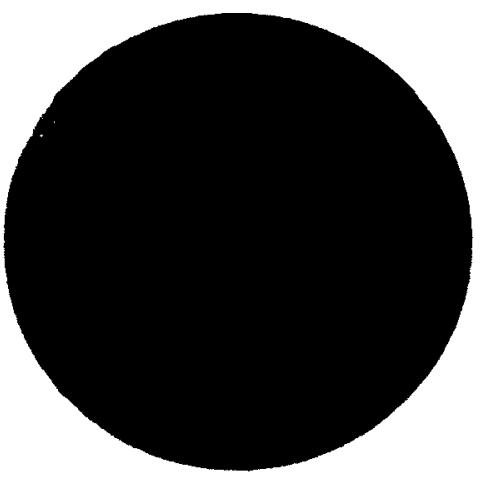

Strongly Agree +2

Agree +1

- Don't Know 0

- Disagree -1

- Strongly Disagree -2

Figure 4. Survey Question 6

The majority of respondents, $64 \%$, indicated they agreed $(+1)$ or strongly agreed $(+2)$ with this survey question. Fourteen percent reported that they disagreed $(-1)$ with the statement that students are evaluated once they are identified and located. Twentytwo percent did not know (0). The mean was 1.8 , and responses ranged from strongly agree to disagree. One administrator who disagreed $(-1)$, reported on the survey, "There is sometimes a longer time lag in completing the process."

In the interviews, administrators were split evenly (one was undecided) on whether or not the LEA followed the child find process of evaluating students. Erica shared: "I agree with that. I've found that once the ball is rolling, the people you work with are very good." However, of importance, she shared that she was unable to remember which public school she worked with to complete the process.

Nathan, who had a different perspective, shared that he understood the constraints of the public school system: "It's a process that is backlogged. They have their own kids, but we need to find out what's going on with our kids as well." 
The fourth survey question that related to Research Question 4 was Number 8 , which addressed the 60-day timeline component of child find. Data are in Figure 5.

The Child Find Process for identifying, locating, and evaluating students in my school with suspected disabilities is completed within the 60-day timeline.

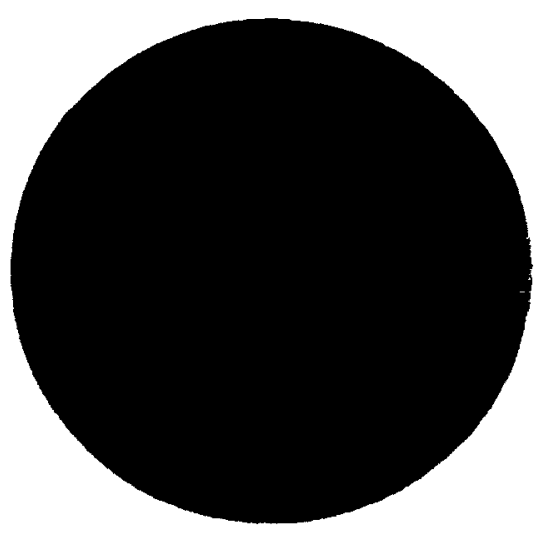

- Strongly Agree +2

- Agree +1

- Don't Know 0

Disagree - 1

Strongly Disagree -2

Figure 5. Survey Question 8

Forty-three percent of administrators indicated that they did not know if the process of identifying, locating, and evaluating students once the District-supplied assessment plan is signed by the parent and returned to the LEA is completed within the 60-day timeline. Thirty-six percent of respondents reported that they disagreed with this statement; however, $21 \%$ reported that they agreed $(+1)$ or strongly agreed $(+2)$ that the activities were completed within the 60-day timeline. The mean is -1 and responses ranged from strongly agree to disagree. This result suggests a gap in perception of the process among administrators. An administrator who disagreed with the statement shared the following in the survey: "There are times that this does not happen as quickly as we would like." 


\section{Research Question 5}

Both survey and interview data were collected to address this question. Research Question 5: "What is the manner and to what extent do Catholic school students with disabilities receive special education and related services through IDEA?"

Several survey questions addressed this research question, and additional data emerged from the optional comment boxes and follow-up interviews. Survey Question Number 3 asked administrators to report which consultation services (indirect services) are provided to teachers and administrators at their school sites. The results are presented in Table 4.

Table 4

Number of Administrators Reporting Occurrence of Indirect Services Indirect services for identified students $\quad$ Frequency reported (14 maximum)

\begin{tabular}{ll}
\hline Academic intervention & 10
\end{tabular}

$\begin{array}{ll}\text { Speech/language } & 7\end{array}$

Occupational therapy $\quad 3$

Assistive technology 3

Other 3

For the respondents who selected Other, the following other "Indirect Services" were reported: "some classroom accommodations," "web resources," and "Special Education meetings." It is worth noting that none of the additional "services" listed, are indeed considered "Indirect Services" under IDEA. 
Tim, the seasoned administrator with experience in several Diocesan schools, commented that he does have "a couple of students enrolled in my school who, after school hours, go to speech through IDEA, but as far as the students we have in the school who have IEPs [sic] we just make the accommodations we can in the classroom."

Title 1 funds are the source of most financial backing, not IDEA funds, for students with disabilities according to the principals I interviewed. Funds are proportionate to the number of students the schools enroll who are from low-income families. Schools receive a higher proportion of Title funds if they serve a higher population of students from low-income families. Title I requires that local educational agencies (LEAs) provide eligible private school children with Title I educational services or other benefits that are equitable to those provided to eligible public school children.

Title I services for eligible private school children are supposed to be developed in consultation with private school officials. The private school does not receive the Title 1, Part A funding; the eligible students enrolled in the private school receive the Title 1, Part A funding. The public school district where the students reside is responsible for making these services available for students in private schools (California Department of Education, 2013).

Nathan, the principal who presides over the school with very limited finances in a high-poverty area, shared the following about the value he places on the Title 1, Part A funding:

We have Title $1-$ I think that's the one area that we do provide focus and our school is an inner city merged school, so we're two campuses for one school. Our primary grades are at one campus and grades four through eight are at another campus. When we have children that are in need, generally in the primary grades, so we have our Title 1 teacher focus on helping those younger kids progress. 
Survey Question Number 12 also addressed this research question. The statement reads: "For students who were identified as having a learning disability, services are provided on my school site through the public school system (e.g., speech and language)" (data are displayed in Figure 6).

For students who were identified as having a learning disability, services are provided on my school site through the public school system.

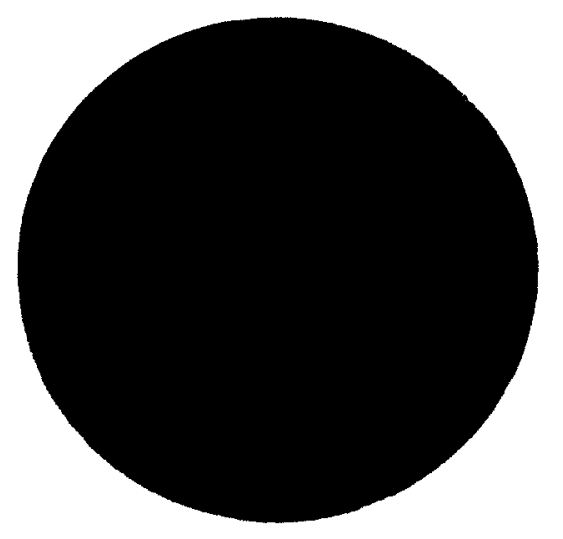

Strongly Agree +2

- Agree +1

- Don't Know 0

- Disagree -1

- Strongly Disagree -2

Figure 6. Survey Question 12

Eighty-six percent of the respondents indicated that they disagreed $(-1)$ or strongly disagreed $(-2)$ with this statement. Seven percent reported not knowing if this occurs $(0)$ and $7 \%$ agreed $(+1)$ that IDEA services are provided on the school site. The mean was -3.8 , and responses ranged from agree to strongly disagree. Erica, the newer administrator, disagreed (-1) and shared her frustration that services are never provided at her school site for students who qualify:

The schools always say, 'Well, if they were at our school, this is the type of services they would get.' But we always respond, 'they're not at your school, is there someone who could come in here and help?' Of course they'll say 'No, we don 't have it in our budget to do it.'

Tim, who strongly disagreed (-2) with the statement, shared a similar experience with his LEA: "One of the things they say is, "If you want those services that we're 
saying you should get, you'll have to enroll,' but basically it's never [the LEA never comes onto the private school site]."

Survey Question Number Question Number 11 asked Catholic school administrators if all students were reported in the annual count for the purpose of generating IDEA services. Data are displayed in Figure 7.

All students in my school who were identified through the public school system were counted for the purpose of generating IDEA services.

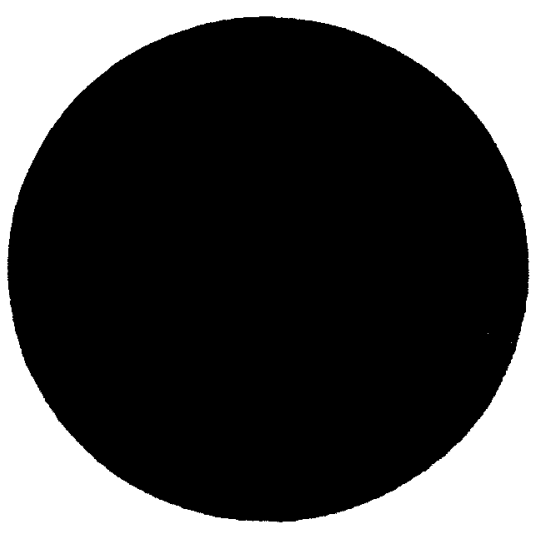

- Strongly Agree +2

- Agree +1

- Don't Know 0

- Disagree - 1

- Strongly Disagree -2

Figure 7. Survey Question 11

Jennifer, the high school administrator, disagreed with this statement and shared that in the annual child find count the public school district sends to her school, the number of identified students is "typically zero," which means it would be highly unlikely that students at her school receive funding through IDEA.

Thirty-six percent of respondents did not know $(0)$ if there was an accurate count and $36 \%$ disagreed $(-1)$ or strongly disagreed $(-2)$. Twenty-eight percent of the administrators surveyed agreed that all students in their schools who were identified were actually counted for the purpose of generating IDEA services. The mean is -0.4 , and the responses ranged from agree to strongly disagree. One respondent's comment typified 
the views of the $36 \%$ of administrators who did not know (0): "How would I know if this were occuring?"

\section{Summary}

This chapter includes a presentation of survey and interview data as it pertained to the five research questions I posed. The overarching consistency identified in the survey and interview data was the confusion Catholic school administrators experience in trying to understand the proper course of action to take when they suspect students at their schools may have disabilities. Many reported inconsistencies in the given legal timeframe and the need to push the process along. Also, as evidenced in the interviews, several of the principals who indicated they had a grasp of the child find process on the survey did not actually have a working knowledge of the legal framework.

The two administrators who viewed their role as advocates for the students with suspected disabilities had greater access to resources that other administrators who did not. For example, although not tied to IDEA funding, one administrator, Nathan, formed a strong relationship with the University of San Diego and was able to access tutors and counselors free of charge. Another administrator, Tim, knew the names of the district personnel at the PPPS office, and frequently communicated with them regarding the needs of his students. He indicated that having a strong relationship with the LEA has increased the accessibility his students had to special education and related services.

\section{Significance of the Study}

The purpose of this study was to capture the landscape of what is happening with public special education within the Diocese of San Diego. Although there were limitations to this study, the potential insight gained from this research is valuable for 
private school administrators and the SDUSD's Parentally Placed Private School Division, which is responsible for facilitating the consultation processes with private school administrators. More importantly, advocates argue that students with disabilities whose parents chose to enroll them in Catholic or other private schools need to be afforded the same services as their public school counterparts. This study reveals several factors that need to be examined in order for that to happen.

In Chapter 5, I present an interpretation of the findings, implications, recommendations for future research, and conclusions. 


\section{CHAPTER FIVE}

\section{RESEARCH SUMMARY, IMPLICATIONS, AND RECOMMENDATIONS}

Many private schools enroll students with identified disabilities. However, there is scarce literature that shows the type of services provided to students in private schools by the public LEA (Taylor, 2005). Additionally, the percentage of identified students with disabilities in public schools is almost double (13.3\%) the percentage of students in Catholic schools (6.83\%; USCCB, 2002).

This study began with a review of the enactment of, and subsequent amendments to IDEA (2004) and its application to both public and private schools. The purpose of the study was to examine the child find process under IDEA as it applies to children with disabilities enrolled in the 14 Catholic schools within the Diocese of San Diego.

Included was information about the extent to which students with disabilities are enrolled in Catholic schools within the boundaries of SDUSD. The survey and follow-up interviews provided insight into types of services made available in these schools for students who are identified as having a disability. Additionally, the study explored how much understanding Catholic school principals have about both child find and special education services under IDEA.

This study used a mixed-methods study design involving a survey of 14 Catholic school administrators and in-depth interviews with five administrators located in the Diocese of San Diego. This approach enabled me to gather quantitative and qualitative data on the child find process and students enrolled in Catholic schools located within the boundaries of SDUSD. This chapter includes a summary of the key findings, 
interpretation of the findings and their implications, and recommendations for future research.

\section{Summary of Research Findings}

\section{Research Question 1}

"How knowledgeable are Catholic school administrators on the child find process?"

Overall, Catholic school administrators included in this study were not knowledgeable on the child find process. Although the majority of respondents claimed they agreed or strongly agreed that they knew how the process worked, subsequent survey questions and interview data presented in Chapter 4 revealed their knowledge of the locating, identifying, and evaluating portions of child find was lacking.

The consistent theme that arose was the positive correlation between what the Catholic school administrators thought they know about the child find process and their satisfaction with their ability to meet the needs of their students with disabilities in their private schools. $\mathrm{Tim}^{3}$, the veteran principal with a solid working knowledge of the process, knows SDUSD private school special education contact person by name and reported being comfortable picking up the phone and calling when he was concerned about a student.

But aside from this one respondent, it was clear that the others interviewed thought they knew the steps in the process, but the survey and interview data revealed

${ }^{3}$ Given the small number of interviewees, I used pseudonyms for those referenced directly. 
that they overestimated their own knowledge. The potential ramifications of this include, but are not limited to misguiding parents in their search for receiving special education and related services, underreporting the number of students with identified disabilities, and compromising Catholic school administrator ability to serve as an advocate for their students with suspected disabilities.

\section{Research Question 2}

"What strategies does the San Diego Unified School District use to make administrators aware of the process?"

For the purpose of this study, I wanted to learn what strategies administrators were aware of and then compare them to the strategies SDUSD reported utilizing. Although the responsibility for making private schools representatives aware of the process legally falls to the public LEA, all respondents reported having to be proactive to ensure their students were located, identified, and evaluated.

On the SDUSD (2013) Parentally Placed Private School Students' website, the district offers assistance with the child find process, but does not take the responsibility for initiating the process:

Pursuant to federal and state law, the San Diego Unified School District has developed policy and procedures to assist private schools in child-find activities, accepting referrals from private schools and others, and administering appropriate assessments for students suspected of having one or more disabilities.

However, according to IDEA (2004), the child find duties are affirmative (34 CFR $\$ 300.111$ ), meaning that neither the parents nor the private school are required to request assessments (initiate the child find process). The child find process is comprehensive and is supposed to extend to all children with disabilities enrolled in private independent and private religious schools. The SDUSD PPPS flowchart on the 
district's website clearly stated that the parent of the student enrolled in the private school has to make a request to initiate the process: Step 1- "Student attends a private school in our district and the parent requests assessment." Because Research Question 1 revealed that many Catholic school administrators within the Diocese do not have a working knowledge of child find, it is highly unlikely that they would be able to help the family of a student with a suspected disability navigate the process. Based on these findings, it is critical that Catholic school administrators are able to direct parents to the district's website so they can access the forms to initiate the assessment process.

\section{Research Question 3}

"To what extent are children with disabilities enrolled in Catholic schools within the Diocese of San Diego?"

The study conducted by USCCB (2002), the latest of its kind, concluded that approximately $7 \%$ of students in Catholic schools nationally have diagnosed special needs compared to over $13 \%$ in public schools. All of the survey respondents in my study indicated they have at least one student enrolled in their school with a disability. I did not learn the exact percentages because I did not want to discourage principals from responding if they knew they would have to locate data that may or may not be readily accessible or if they felt uncomfortable reporting a number.

Durow (2007) stated that the missions of Catholic schools lean toward inclusive practices when it comes to student enrollment; however, he noted that practices are inconsistent across schools. Gray and Gautier (2006) also reported inconsistencies among Catholic school leaders and their attitudes about enrolling students with disabilities. They report that $47 \%$ of leaders in Catholic schools stated that they are 
unable to accommodate students with special needs and/or disabilities. Durow (2007) postulated that one of the most significant barriers to being fully inclusive is lack of financial resources.

Durow's (2007) findings correspond to the data collected in this study. The major obstacle identified to enrolling students with suspected disabilities/disabilities in the Diocese of San Diego appears to be funding. The USCCB (2002) study found that when the child find process works and the child is determined to have a disability, providing services for the child with special needs is challenging. The same study also revealed only $13 \%$ of the cost of special education and related services for Catholic school students with disabilities was funded by IDEA at the time the USCCB research was conducted.

All of the interviewees in this study indicated that funding was a significant obstacle in meeting the needs of students with disabilities at their site. A review of the data shows that it is likely that administrators are unintentionally underreporting the number of students at their schools with disabilities. For instance, Jennifer, the high school administrator, said that her school typically reports enrolling no students with disabilities because she feels IDEA does not affect students at her secondary school. It seems highly unlikely in a school enrolling hundreds of students that there would be no students with any type of disability. It is a possibility that they could be underreporting because they know that if the child is to continue to be enrolled in the school, the child will only recieve very limited services under IDEA. Thus, the private school will have to come up with additional funds to meet the needs of students with special needs or risk losing the student to a public school where a FAPE would be provided. Because funding 
is dependent on the number of students reported, this difficulty adversely affects the amount of funding for students who are parentally placed in private schools within the boundaries of SDUSD.

It is important to note that other evidence suggests that Catholic schools do not always exhibit practices and policies reflective of social justice education, particularly when it comes to creating effective service delivery models for students with special needs and English language learners (Weaver \& Landers, 2000). The values of Catholic social teaching emphasizing human dignity, the common good, and a preferential option for the marginalized, compel the public LEA to work together with Catholic dioceses to design service delivery that is inclusive and avoids exclusionary practices.

\section{Research Question 4}

"Given IDEA regulations, how does the child find process operate for parentally placed Catholic school children who may have a disability?"

The child find process is inconsistent across SDUSD. Because each private school must work with their neighborhood public school, consistency is lacking. Each public school has a different culture, and the accessibility would depend on the views LEA administrators have about working with parentally placed private school students. If Catholic school administrators are not familiar with the process, they would not know the procedural safeguards in place to help ensure private school students are given the same consideration in the process as their public school counterparts. Tim, the veteran Catholic school administrator, shared that once a different principal took charge at the local public elementary school, the process was much smoother than it was with the previous principal. Tim lamented that the previous principal at the local public school 
denied any request he made on behalf of a student, so as a result Tim sought assistance from staff of the PPPS division who were able to help him navigate the special education process.

David Conner from the office of PPPS in SDUSU stated that proactive principals definitely receive more assistance from his office than those who are not proactive. This is only because these proactive principals make their needs known. However, his staff oversees approximately 45 private schools including the 19 Catholic schools located in SDUSD and the staff consists of only two full-time ed specialists, one part-time psychologist, one part-time speech/language pathologist, and one part-time registrar. Understandably, one could reason that the office of PPPS would be overextended.

Most Catholic school administrators in the Diocese of San Diego within SDUSD are unsure how the child find process operates for parentally placed Catholic school students who may have a disability. As noted in the previous chapter, the majority of the participants reported in the survey that they did not know, disagreed, or strongly disagreed that the LEA follows the child find process. However, almost all of the respondents who agreed or strongly agreed that they were familiar with the process showed in follow-up survey questions that they could have overestimated their actual knowledge. For example, one administrator agreed that he or she was familiar with the process, but in a subsequent question, the administrators checked off, "I don't know" when asked if identified students at his school were provided with Special Education Individualized Service Plans under IDEA. As noted below, lack of knowledge by Catholic school administrators about services available under IDEA to their students was a significant finding of this study. 


\section{Research Question 5}

"How and to what extent do Catholic school students with disabilities receive special education and related services through IDEA?"

There is a tremendous amount of individual interpretation and inconsistency at the local level. To make matters more complicated, IDEA funds are so limited that they are usually directed to disabilities needing less intervention and lower levels of services (USCCB, 2002). These limits mean students with moderate to severe disabilities would be even less likely to receive services if attending a private or Catholic school. Most schools did report receiving at least one type of indirect service through IDEA, such as academic intervention, speech/language, occupational therapy, or assistive technology. However, administrators shared great frustration that students are not entitled by law to receive services on site at their private schools. One survey respondent did state that this was occurring on his or her private school site. Tim, the seasoned administrator, reported that two or three students receive speech and language services after school through IDEA, but not at his school site.

It is worth noting that the principals working at Catholic schools in low-income areas reported relying primarily on Title 1 funds, not IDEA funds, to help meet the needs of their students requiring direct services. Nathan, the principal of such a school, stated that his school employs a full-time special education teacher paid for through Title 1 funds.

\section{Limitations of this Study}

This research study was conducted in the spring of the 2012-2013 school year. However, administrators based their responses solely on the 2012-2013 school year. The 
study does not reflect any changes in diocesan or district policy after data were collected. Additionally, because this research is rooted in a dynamic legal framework, it is not possible to control for any legislation that may change.

This study only included Catholic schools within the SDUSD boundaries, which is another delimitation. Additionally, the sample size was restricted to 19 administrators and five did not participate. The ability to generalize to other regions and other private schools is limited. Still, the data should be useful in moving the Diocese of San Diego forward in consultation processes with the public school system. Additionally, as Merriam (1998) stated, "A small sample is selected precisely because the researcher wishes to understand the particular in depth, not to find out what is generally true of the many."

\section{Recommendations for Future Research}

This study only focused on 14 Catholic schools in San Diego. Since 2002 (before the 2004 reauthorization of IDEA), there has not been a wide-scale study examining the state of special education in Catholic schools. It would be worthwhile to conduct another nationwide study and examine the variance between states and school districts regarding child find and services provided to students with disabilities in Catholic schools. Additionally, more knowledge of Catholic school principals' attitudes about enrolling students with special needs in their schools would add greater depth to the research. The line of questioning in this study did not probe to discover attitudes and beliefs on inclusive education in Catholic schools.

This study only examined the knowledge Catholic school principals have on child find. It did not examine the knowledge of other potential student advocates, such as 
parents of students with suspected disabilities. Finally, research on special education for private school students is needed for the possibility of effecting legislative change in special education policies for students parentally enrolled in private schools.

\section{Summary}

In the Diocese of San Diego, most administrators are not knowledgeable about the child find process, so it could be more challenging for them to advocate for their students who have suspected disabilities. Administrators who are knowledgeable have a more positive perception of the child find process and appear to be better able to advocate for their students.

This study also determined that all 14 Catholic schools report enrolling at least one student with a disability, but administrators disagree or do not know if they report an accurate count each year in the child find annual survey. Finally, I learned that Catholic school administrators in low-income areas rely more on Title 1 funding than on IDEA to help meet the needs of their students, not IDEA generated funds. Administrators who work in Catholic schools in higher income areas rely on the Catholic school itself and/or parents of students with disabilities for financial support for providing services to enrolled students with disabilities.

Without legislative reform, it is unlikely the landscape will change. Parents will be confronted with the difficult choice: Enroll in a Catholic school and possibly give up the right to essential services for their children or enroll in a public school in order to obtain the right to services. This choice is especially difficult for families with multiple children who may only have one child in need of direct services. Therefore, in the near term, services will need to be provided either by the Catholic school or by the families of 
students with special needs if these students are to receive the services they need while remaining enrolled in Catholic schools. 


\section{REFERENCES}

Agostini v. Felton, 521 U.S. 203 (1997).

Aguilar v. Felton, 437 U.S. 402 (1997).

Alt, M. M., \& Peter, K. (2002). Private schools. A brief portrait. Washington, DC: National Center for Education Statistics.

Americans With Disabilities Act of 1990, Pub. L. No. 101-336, § 2, 104 Stat. 328 (1991).

Cain v. Archdiocese of Kansas City, 508 F. Supp. 1021 (C.D. Kansas 1981).

California Department of Education. (2013, June 21). Title 1 Services for Students in Private Schools. http://www.cde.ca.gov/sp/sw/tl/privateschoolsvs.asp).

Creswell, J. W. (2007). Qualitative inquiry and research design: Choosing among five traditions. London, England: SAGE.

Defiore, L. (2006). The state of special education in Catholic schools. Catholic Education: A Journal of Inquiry and Practice, 9, 453-466. Retrieved from http://digitalcommons.Imu.edu/ce/

Durow, W. P. (2007). Including and Serving Students With Special Needs in Catholic Schools: A Report of Practices. Catholic Education: A Journal of Inquiry and Practice, 10(4), n6. Retrieved from Retrieved from http://digitalcommons.Imu.edu/

Gray, M. M., \& Gautier, M. L. (2006). Latino/a Catholic leaders in the United States. In Emerging Voices, Urgent Choices: Essays on Latino/a Religious Leadership (pp. 65-90). Leiden, Netherlands: Brill Academic Publishers.

Individuals With Disabilities Education Act, 20 U.S.C. $\$ 1400$ (2004). 
Katsiyannis, A., \& Maag, J. W. (1998). Serving children with disabilities in private and parochial schools. Remedial and Special Education, 19, 285-290. doi:10.1177/074193259801900504

Kvale, S., \& Brinkmann, S. (2009). Interviews (2nd ed.). Thousand Oaks: SAGE Publications.

Mawdsley, R. D. (2000). Legal problems of religious and private schools. Dayton, OH: Education Law Association.

Merriam, S. B. (1998). Qualitative research in practice. San Francisco, CA: Jossey-Bass. Mitchell v. Helms, 530 U.S. 793 (2000).

National Association of Independent Schools. (2006).

No Child Left Behind Act of 2001, Pub. L. No. 107-110, §115, Stat. 1425 (2002).

Pacer Center. (2012). [Homepage]. Retrieved from http://www.fape.org

Patton, M. Q., \& Patton, M. Q. (1990). Qualitative evaluation and research methods. Newbury Park, CA: Sage Publications.

Russo, C., Osborne, A., Jr., \& Massucci, J. (2009). The law of special education and nonpublic schools. Plymouth, England: R\&L Education.

Russo, C. J., Massucci, J. D., Osborne, A. G., \& Cattaro, G. M. (2002). Catholic schools and the law of special education: A reference guide. Washington, DC: National Catholic Education Association.

Saldana, J. (2009). The coding manual for qualitative researchers. London, England: Sage.

San Diego Unified School District. (2013). [Home page]. Retrieved from http://www.sandi.net/page/2053 
Scanlan, M. K. (2009). All are welcome: Inclusive service delivery in Catholic schools. Notre Dame, IN: Alliance for Catholic Education.

Rehabilitation Act of 1973, Pub. L. No. 93-112, 87 Stat. 355 (1973).

Shaughnessy, M.A. (1998). Selected legal issues in Catholic schools. Washington, DC: National Catholic Educational Association.

Shaughnessy, M. A. (2005). The law and Catholic schools: A guide to legal issues for the third millennium. Washington DC: National Catholic Educational Association.

Taylor, S. S. (2005). Special education and private schools. Remedial and Special Education, 26, 281-296. doi:10.1177/07419325050260050301

United States Conference of Catholic Bishops. (2002). Catholic school children with disabilities. Washington, DC: Author.

U.S. Department of Education. (2004).

Wasserman, L. M. (2009). The rights of parentally placed private school students under the Individuals with Disabilities Education Improvement Act of 2004 and the need for legislative reform. Brigham Young University Education and Law Journal, 2009(1), 131-172. Retrieved from http://lawlib.wlu.edu/

Weaver, R., \& Landers, M. F. (2000). Our vocation: To serve all. Momentum, 31(3), 2831. Retrieved from http://www.ncea.org/

Wright's Law. (2012). [Homepage]. Retrieved from http://www.wrightslaw.com Zobrest v. Catalina Foothills School District, 509 U.S. 1 (1993). 